\title{
Contact-mediated Mechanisms of Motor Axon Segmentation
}

\author{
Robert A. Oakley ${ }^{1, a}$ and Kathryn W. Tosney ${ }^{1,2}$ \\ ${ }^{1}$ Neuroscience Program and ${ }^{2}$ Biology Department, The University of Michigan, Ann Arbor, Michigan 48109
}

In the chick embryo, the segmental pattern of motor outgrowth depends on guidance cues provided by sclerotome cells. Motor axons preferentially invade the anterior sclerotome but avoid the posterior sclerotome. To determine how motor growth cone motility is influenced by these cells, we used videomicroscopy to analyze the behavior of motor growth cones as they confronted identified sclerotome cells in vitro. After contact, motor growth cones invariably avoided posterior sclerotome cells by either branching or turning. Both types of avoidance behavior were initiated by a local inhibition of veil protrusion: veils failed to progress along the contacting filopodia. This inhibition was specific to veils since contact failed to alter the number of filopodia protruded. Moreover, motor growth cones turned away from posterior cells despite more persistent filopodial contacts with these cells than with the laminin substratum. In no case did contact with posterior cells cause a complete loss of growth cone motility or a complete collapse of growth cone structure. In contrast, motor growth cones exhibited a selective affinity for anterior cells, preferring the surfaces of these cells to the laminin substratum. Contact with anterior cells stimulated a generalized increase in protrusive activity: contact caused a net increase in the extension of veils and filopodia both locally and at sites distant from the site of contact. Contact also elicited a localized thickening of contacting processes, suggesting that contact with anterior cells promotes neurite consolidation. This behavior of motor growth cones in vitro suggests that both an inhibition of veil formation by posterior cells and an enhancement of motility and axon consolidation by anterior cells contribute to the preferential advance of motor axons into anterior sclerotome in vivo. We suggest that patterned outgrowth results from the juxtaposition of two contrasting environments that differentially influence growth cone motility.

[Key words: axon guidance, growth cones, segmentation, inhibition, motoneurons, cell motility]

\footnotetext{
Received Dec. 15, 1992; revised Mar. 1, 1993; accepted Mar. 10, 1993.

This work was supported by NIH Grant NS-21308 to K.W.T. R.A.O was partially supported by NIH Training Grant HD-07274 and by a Rackham predoctoral fellowship from the University of Michigarl. We thank Carol Erickson for providing the HNK-1 antibody. We thank Denise Dehnbostle and Kay King for technical assistance and David Bay for photographic assistance. For assistance during the initial phase of this study, wc thank Jonathan Raper, Friedrich Bonhoeffer, and the Max-Planck-Institut fur Entwicklungsbiologie. We also thank Kate F. Barald, Stephen S. Easter, Jr., Richard I. Hume, and John Y. Kuwada for critical reading of the manuscript.

Correspondence should be addressed to Kathryn W. Tosney, Natural Science Building, The University of Michigan, Ann Arbor, MI 48109.

a Present address: Department of Neurobiology, University of Pittsburgh, School of Medicine, Pittsburgh, PA 15261.

Copyright (C) 1993 Society for Neuroscience $0270-6474 / 93 / 133773-20 \$ 05.00 / 0$
}

A critical step in the formation of specific neural connections is the initial guidance of axons to their targets. In a variety of developing systems, axons take specific, stereotyped routes to their targets, in many cases traveling over long and complex trajectories (Lance-Jones and Landmesser, 1981a,b; Ball et al., 1985; Tosney and Landmesser, 1985b,c; Eisen et al., 1986; Johansen et al., 1989). The specific paths traced out by axons have long been believed to result from environmental influences on the behavior of the motile tip of the axon, the growth cone (Ramon y Cajal, 1890; Harrison, 1910). However, in most cases, very little is known about how physiologically relevant guidance cues influence motile behavior and cause growth cones to turn.

Growth cone advance can be usefully divided into three sequential events: protrusion, engorgement, and consolidation, which may be differentially affected by guidance cues (Goldberg and Burmeister, 1986, 1989). The sequence begins with the protrusion of organelle-free veils and filopodia, with veils typically extending between adjacent filopodia. Next, some of the extended veils become engorged: they are invaded by organelles, microtubules, and cytoplasm from the body of the growth cone. The engorgement step thus effectively translocates the body of the growth cone forward into the extended veils. Finally, the nascent axon becomes consolidated behind the advancing body of the growth cone. During the consolidation step, the region of the former body loses some attachments to the substratum, and becomes less flattened and more cylindrical. Although it is not yet known if any of these steps are selectively influenced by guidance cues, recent experiments on grasshopper sensory pioneers suggest that positive cues may influence the engorgement step (Sabry et al., 1991).

As shown by culture studies, growth cones can respond to both positive and negative stimuli that may influence the direction of outgrowth. For example, growth cones will turn toward sources of diffusible agents (Letourneau, 1978; Gundersen and Barrett, 1980) or toward the cathode in an applied electrical field (Hinkle et al., 1980; Patel and Poo, 1982). Similarly, growth cones will turn onto a more adhesive substrate when given a choice between artificial substrates (Letourneau, 1975), although adhesion alone may not dictate the direction of outgrowth on naturally occurring substrates (Gundersen, 1987; Calof and Lander, 1991; Lemmon et al., 1992). Culture studies have also documented negative influences on growth cone advance. For example, some growth cones exhibit a striking loss of motility upon contact with specific neurites (Kapfhammer and Raper, 1987a,b) or glial cells (Bandtlow et al., 1990). A similar loss of motility can also be elicited in some growth cones in response to neurotransmitters (Haydon et al., 1984) or to other manipulations that drastically alter intracellular calcium (Cohan et al., 1987; reviewed by Kater and Mills, 1991).

Although these in vitro studies have established that growth 
cones can respond to a wide range of stimuli, very few studies have documented the behavioral responses of growth cones to cues known to provide guidance information in vivo. In this report we have analyzed the behavior of chick motor growth cones as they interact with identified cells that are known to be essential for their guidance in the embryo. We focus on one of the two experimentally dissociable classes of cues that are known to guide motor growth cones, general cues. Unlike specific cues that influence only specific subpopulations and direct the deployment of these axons where multiple common pathways diverge, general cues influence all subpopulations of motor axons and define the common pathways of axon outgrowth (LanceJones and Landmesser, $1981 \mathrm{a}, \mathrm{b}$; for review, see Landmesser, 1988; Tosney, 1991).

A striking example of guidance by general cues is the segmental patterning of motor axons that results in the formation of reiterated spinal nerves. This segmental pattern is dependent on interactions with the somites, the repeating blocks of mesoderm that lie adjacent to the neural tube (Detwiler, 1934). In the chick, the segmental pattern is established as motor growth cones preferentially invade the anterior half of each somite both during normal development and after experimental reversal of the somites (Keynes and Stern, 1984). Deletions of somite derivatives have conclusively shown that interactions with the sclerotome are essential for segmental patterning. In the absence of sclerotome, motor axons extend from the neural tube as an uninterrupted sheet (Tosney, 1987, 1988). However, sclerotome deletion does not disrupt the selective projection of motor axon subpopulations to specific muscles; it only alters the gross anatomical pattern of outgrowth. Thus, sclerotome cells provide general rather than specific guidance cues.

Three lines of evidence suggest that posterior sclerotome cells may guide motor growth cones by restricting their advance. First, deletion of the sclerotome allows the spatial expansion of motor outgrowth, as if an inhibitory influence had been removed (Tosney, 1988). Second, compound somites consisting solely of posterior half segments exclude motor axons (Stern and Keynes, 1987). Finally, somite extracts cause sensory growth cones to collapse in vitro. Since the collapsing activity can be removed with antibodies and lectins that selectively label the posterior sclerotome, this tissue may inhibit the motility of sensory growth cones (Davies et al., 1990).

To determine how growth cone motility is altered by physiologically relevant guidance cues, we used video microscopy to analyze the behavior of motor growth cones as they confronted sclerotome cells in vitro. We found that filopodial contact with posterior cells locally inhibits veil protrusion. In contrast, filopodial contact with anterior cells stimulates both protrusive activity and the consolidation of the nascent ncuritc.

\section{Materials and Methods}

Cell culture and vital dye labeling. Sclerotome cells were isolated from $3 \mathrm{~d}$ chick embryos (stage 18; Hamburger and Hamilton, 1951) that were decapitated, eviscerated, and washed in Hank's balanced salt solution (HBSS). To gain access to the sclerotomal portion of the somites, the notochord and spinal cord were removed from the hindlimb region. The preparations were then washed extensively in HBSS and transferred to HBSS containing $10 \%$ heat-inactivated horse serum. Small aliquots of cells are then removed from within either the anterior or posterior half of each somite using suction into flame-polished micropipettes (tip size, 40-60 $\mu \mathrm{m}$ ) under visual control (see Fig. 1).

Each isolated subpopulation was then fluorescently labeled for subsequent identification in cocultures with spinal cord cells using the fol- lowing modifications of a procedure described by Honig and Hume (1986). For each culture, subpopulations of sclerotome cells from six embryos were pooled and transferred to growth medium (see below). The cells were then pelleted and resuspended in $1 \mathrm{ml}$ of growth medium that contained $50 \mu \mathrm{l} / \mathrm{ml}$ of the green fluorescent lipophilic dye 3,3'dioctadecyloxacarbocyanine perchlorate (DiO; $4 \mathrm{mg} / \mathrm{ml}$ in $90 \%$ ethanol, $10 \%$ dimethyl sulfoxide; Molecular Probes). Following a $45 \mathrm{~min}$ incubation at $37^{\circ} \mathrm{C}$, the cells were pelleted, washed three times, and finally resuspended in $100 \mu \mathrm{l}$ of growth medium containing $4 \%$ bovine serum albumin (BSA). Each cell suspension was then plated into the center well of a $35 \mathrm{~mm}$ glass-bottomed petri dish containing $2 \mathrm{ml}$ of growth medium. The cells were allowed to attach for at least $3 \mathrm{hr}$ prior to the addition of spinal cord cells and all recordings were made between 12 and $30 \mathrm{hr}$ thereafter. Acid-washed glass substrates were prepared in advance by treating with polyornithine (Sigma; $1 \mathrm{mg} / \mathrm{ml}$ in water) and laminin (GIBCO/Bethesda Research Labs; $100 \mu \mathrm{g} / \mathrm{ml}$ in $0.05 \mathrm{M}$ carbonate buffer, $\mathrm{pH}$ 9.6) to promote cell attachment and neurite outgrowth.

To identify motor growth cones, motor neurons were retrogradely labeled by dye injection into the spinal nerves prior to culturing spinal cord cells. Four day chick embryos (stage 22-24) were washed in Tyrode's buffer, decapitated, and eviscerated. The notochord and the associated ventral sclerotome were then removed to reveal the ventral aspect of the spinal cord and the spinal nerves. Spinal nerves at the hindlimb level were pressure injected with a solution of the red fluorescent lipophilic dye $1,1^{\prime}$-dioctadecyl-3,3,3',3'-tetramethylindocarbocyanine perchlorate (Dil; $2.5 \mathrm{mg} / \mathrm{ml}$ in $90 \%$ ethanol, $10 \%$ dimethyl sulfoxide; Molecular Probes) using broken micropipettes. The preparations were then incubated for $18-24 \mathrm{hr}$ at $32^{\circ} \mathrm{C}$ in an oxygenated Tyrode's bath to allow for retrograde dye transport and labeling of motor neuron cell bodies. The ventrolateral spinal cord from the hindlimb region was then carefully removed, minced, transferred to $5 \mathrm{ml}$ of Puck's saline $\mathrm{G}$ containing $1 \times$ trypsin (GIBCO), and incubated for $5-10 \mathrm{~min}$ at $37^{\circ} \mathrm{C}$. The reaction was quenched with $5 \mathrm{ml}$ of growth media. The cells were pelleted and then dissociated by trituration in growth medium through flame-reduced Pasteur pipettes. Approximately $1-3 \times 10^{4}$ spinal cord cells were added to each dish containing either anterior or posterior somite cells. These cocultures were maintained at $37^{\circ} \mathrm{C}$ under $5 \% \mathrm{CO}_{2}$ in Ham's F12 media supplemented with $10 \%$ heat-inactivated horse serum, antibiotics (GIBCO/Rethesda Research Labs), and hormone additives (Bottenstein et al., 1980). In some experiments the trypsin was omitted; this did not alter the behavior of motor growth cones, so the data were combined.

Videomicroscopy. Interactions between motor growth cones and sclerotome cells were recorded using a Diaphot (Nikon) inverted microscope and an intensified CCD videocamera (Pulnix model TM-74, Motion Analysis, Eugene, OR) connected to a Zenith 386 computer with the Image-1/AT image analysis package (Universal Imaging). Using this system, low light levels were used to produce phase-contrast images that were digitized, averaged, background subtracted, and contrast enhanced. Images were recorded using either a Gyyr time-lapse video recorder set to give a 12 -fold time compression, or a Panasonic optical disk recorder (model 2028) set to record 15 frames/min. For analysis, recorded images were played back into the computer through a time base corrector (For-A model FA-300) and videotape records were transferred to optical disks. For presentation, selected frames were photographed directly from the monitor using T-Max film (ISO-100, Kodak).

For each recording session, culture dishes were filled with preequilibrated growth medium, sealed, and mounted on a microscope stage maintained at $37^{\circ} \mathrm{C}$ by a recirculating water bath and a proportional temperature control device. Cultures were scanned using low-power $(20 \times)$ phase contrast and potential interactions were identified based on morphology and predicted trajectory. The identities of the growth cone and mesenchymal cell were then established using brief pulses of epifluorescent excitation light that was highly attenuated with neutral density filters. Interactions of interest were then recorded using phasecontrast optics ( $40 \times$ or $60 \times$ oil Nikon phase/fluor objectives). To prevent phototoxicity, transmitted light was reduced with two heat-absorbing filters, an ND-16 neutral density filter, a green interference filter (all from Nikon), and a yellow acetate gel filter (Rosco, "medium straw"; see Moorman and Hume, 1990).

To establish the preinteraction behavior of growth cones and somite cells, each potential interaction was observed for at least $20 \mathrm{~min}$ prior to contact between cells. We analyzed only those growth cones that made steady progress toward the cell without stopping, collapsing, or 
branching spontaneously. The precontact period was also used to screen out interactions with putative neural crest cells, the highly motile and filopodial DiO-labeled cells that were occasionally observed in anterior but not posterior cultures (see below). A total of seven interactions were rejected based on behavior during the precontact period.

Immunocytochemistry. To establish the selectivity of the sclerotome cell isolations, anterior and posterior sclerotome cells were isolated as above but without dye labeling, cultured overnight without the addition of neurons, and double labeled with peanut agglutinin (PNA) and the HNK-1 monoclonal antibody (see Fig. 2). Cultures were washed in Krebs' buffer (Meiri and Burdick, 1991) containing 0.4 M sucrose (Krebs'/ sucrose) and fixed overnight at $4{ }^{\circ} \mathrm{C}$ in $4 \%$ paraformaldehyde with $0.5 \%$ cetylpyridinium chloride in Krebs'/sucrose. Cultures were washed, incubated in $0.02 \mathrm{M}$ glycine in PBS, washed, and blocked in HEPESbuffered saline (HBS: $10 \mathrm{~mm}$ HEPES, $0.15 \mathrm{M} \mathrm{NaCl}, 0.1 \mathrm{~mm} \mathrm{CaCl}_{2}$ ) containing $1 \%$ BSA. Cultures were then incubated for $60 \mathrm{~min}$ in PNA $(20 \mu \mathrm{g} / \mathrm{ml}$ in block; Vector), washed, and incubated for $60 \mathrm{~min}$ in mixture of goat anti-PNA (1:100) and HNK-1 (1:250) in block. The cultures were washed, incubated in block containing $10 \%$ normal rabbit serum, incubated for $60 \mathrm{~min}$ in mixed secondary antibodies (rabbit anti-goatfluorescein isothiocyanate and rabbit anti-mouse-rhodamine isothiocyanate, 1:50 in block with normal rabbit serum), and washed. Unless otherwise noted, all washes were in three changes of PBS.

Since migrating neural crest cells colonize the anterior somite along with anterior sclerotome cells, we also used the HNK-1 monoclonal antibody to distinguish between anterior sclerotome cells and crest cells following video recording. Anterior cultures were fixed with $4 \%$ paraformaldehyde in Krebs'/sucrose at $4^{\circ} \mathrm{C}$ overnight and reacted with the HNK-1 antibody as described above except that PNA and related reagents were omitted. The anterior somite cell previously videotaped was then reidentified and defined as an anterior sclerotome cell if it was HNK-1 negative.

Image analysis. For analysis, interactions with sclerotome cells were categorized as being either perpendicular or oblique. Perpendicular interactions were those in which both sides of the growth cone made contact with the cell (see Figs. 4, 6, 10). Oblique interactions were those in which the growth cone approached the cell such that processes on only one side of the growth cone contacted the cell while those on the other side contacted only the substratum (see Figs. 8, 12).

To analyze contact-dependent changes in the shape and behavior of motor growth cones, pre- and postcontact measurement periods were defined for 10 perpendicular interactions ( 5 with anterior and 5 with posterior sclerotome cells). Precontact periods were defined as time periods (4-10 $\mathrm{min}$ ) prior to any visible filopodial contact, whereas the postcontact period was defined as an equal time period after the establishment of filopodial contact that was stable (contact lasting longer than a minute). Between the two measurement periods, there was commonly a variable period of transient filopodial contact, when one or many filopodia touched but did not adhere to the cell.

To determine which aspects of growth cone behavior were affected by contact with sclerotome cells, we compared three different measures of growth cone motility before and after contact in perpendicular interactions. First, we used the surface area of the flattened portion of the growth cone as a gauge of the overall extent of veil protrusion. We measured the flattened portion of the growth cone once a minute during each measurement period. Filopodia and consolidated, phase-dark regions of the growth cones were excluded from the surface area measurements. Second, to detect changes in the rate of protrusive activity, we measured the rate of veil advance during the same time periods. The rate of protrusion of prominent veils was tracked by first identifying sites where an individual veil extended at least $2 \mu \mathrm{m}$ from the leading edge of the growth cone. The veil was then followed to its most distal extent. The rate of advance was calculated based on the time necessary to protrude the veil from the leading edge to its most distal extent. For every growth cone, an individual veil was tracked for each minute of each measurement period. Finally, to detect changes in filopodial protrusion, we counted the number of filopodia present once a minute during each measurement period.

For statistical comparisons, the mean precontact values were compared to the mean postcontact values of individual growth cones using the paired Student's $t$ test. For presentation of data from growth cones with different sizes and shapes, the quantitative data were normalized by expressing all values as a percentage of the precontact mean. The figures (see Figs. 3, 5, 11) illustrate the means and standard errors of the normalized data. We also measured the overall rate of growth cone
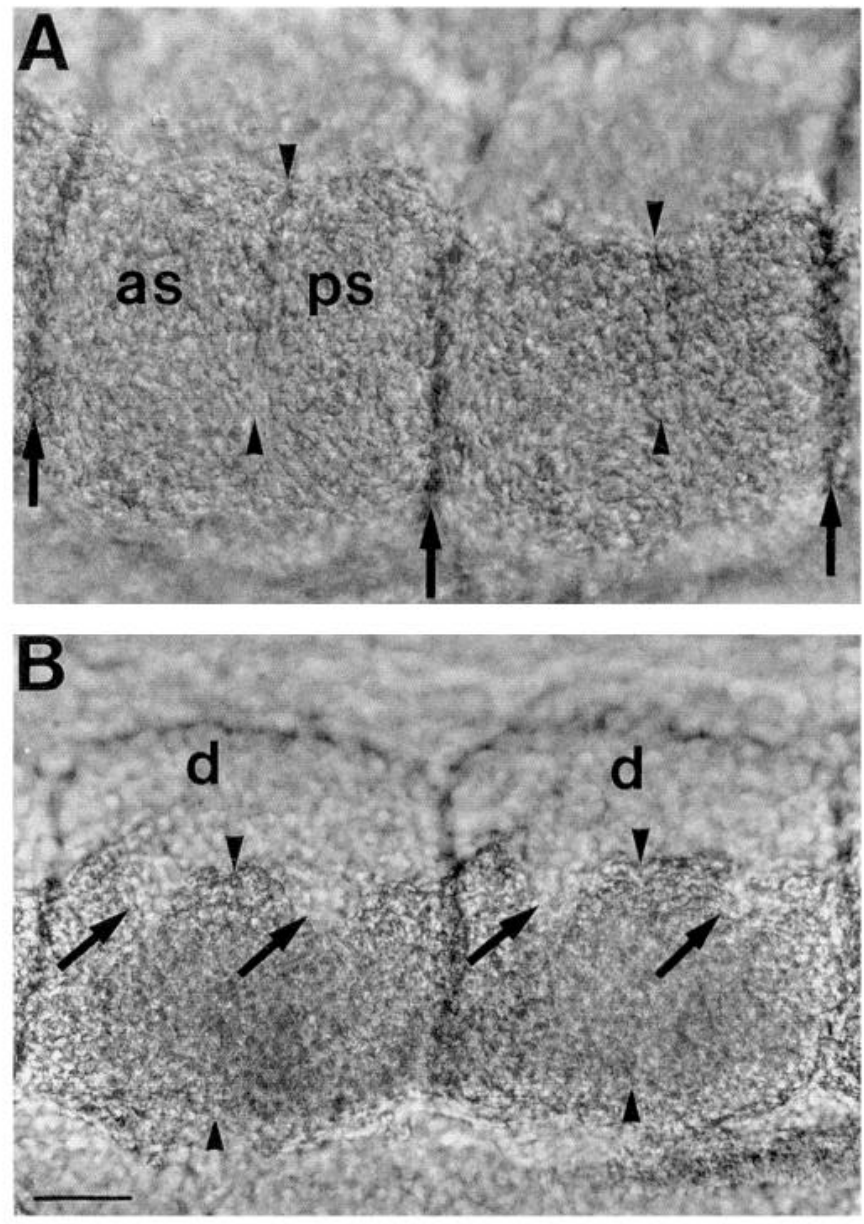

Figure 1. Selective removal of anterior and posterior sclerotome cells. $A$, Nomarski image of a somite preparation before the removal of sclerotome cells. The viscera, spinal cord, and notochord have been removed to reveal the medial aspect of the sclerotome. Borders between somites (arrows) are clearly visible, as is the fissure (between arrowheads) between the anterior (as) and posterior ( $p s)$ sclerotome within each somite. $B$, Similar preparation (slightly younger) after selective removal of small plugs of cells (arrows) from both the anterior and posterior sclerotomes. The fissure between the sclerotomes (between arrowheads) is out of the focal plane as is the dermamyotome $(d)$. Medial is up; posterior is to the right. Scale bar, $50 \mu \mathrm{m}$.

advance during each measurement period and compared the means of normalized growth rates using the paired Student's $t$ test.

To determine whether contact with sclerotome cells had localized or general effects on growth cone motility, we analyzed oblique interactions. We compared the side of the growth cone contacting the cell to the side of the growth cone contacting only the substratum. We defined a measurement period of 20-30 min that was after the establishment of stable filopodial contact, but before the growth cone turned away from or grew onto the sclerotome cell. The growth cone image was divided in half along the axis of the neurite and the surface area and number of filopodia on each side were measured once every $3 \mathrm{~min}$ during the measurement period. For each image, the values for each side of the growth cone were normalized by expressing each value as a percentage of the total of both sides. The mean of these normalized values for each interaction was then averaged with those of similar interactions for statistical comparison using the Student's $t$ test. The figures (Figs. 9, 13) illustrate the means and standard errors of the normalized data. We also compared the duration of filopodial contacts on the cells to the duration of those on the laminin substratum during the same measurement period. The means of the raw data were compared using the Student's $t$ test. All measurements were made using images from the optical disk recorder and the Image-1 (Universal Imaging) image analysis system. 

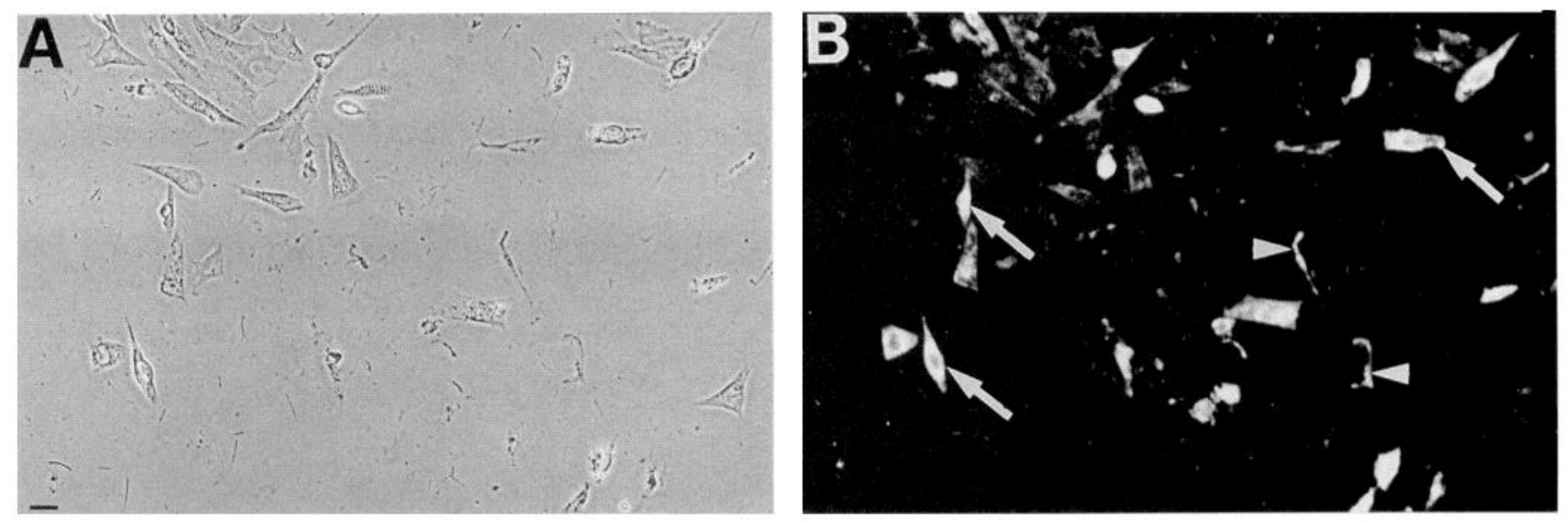

C
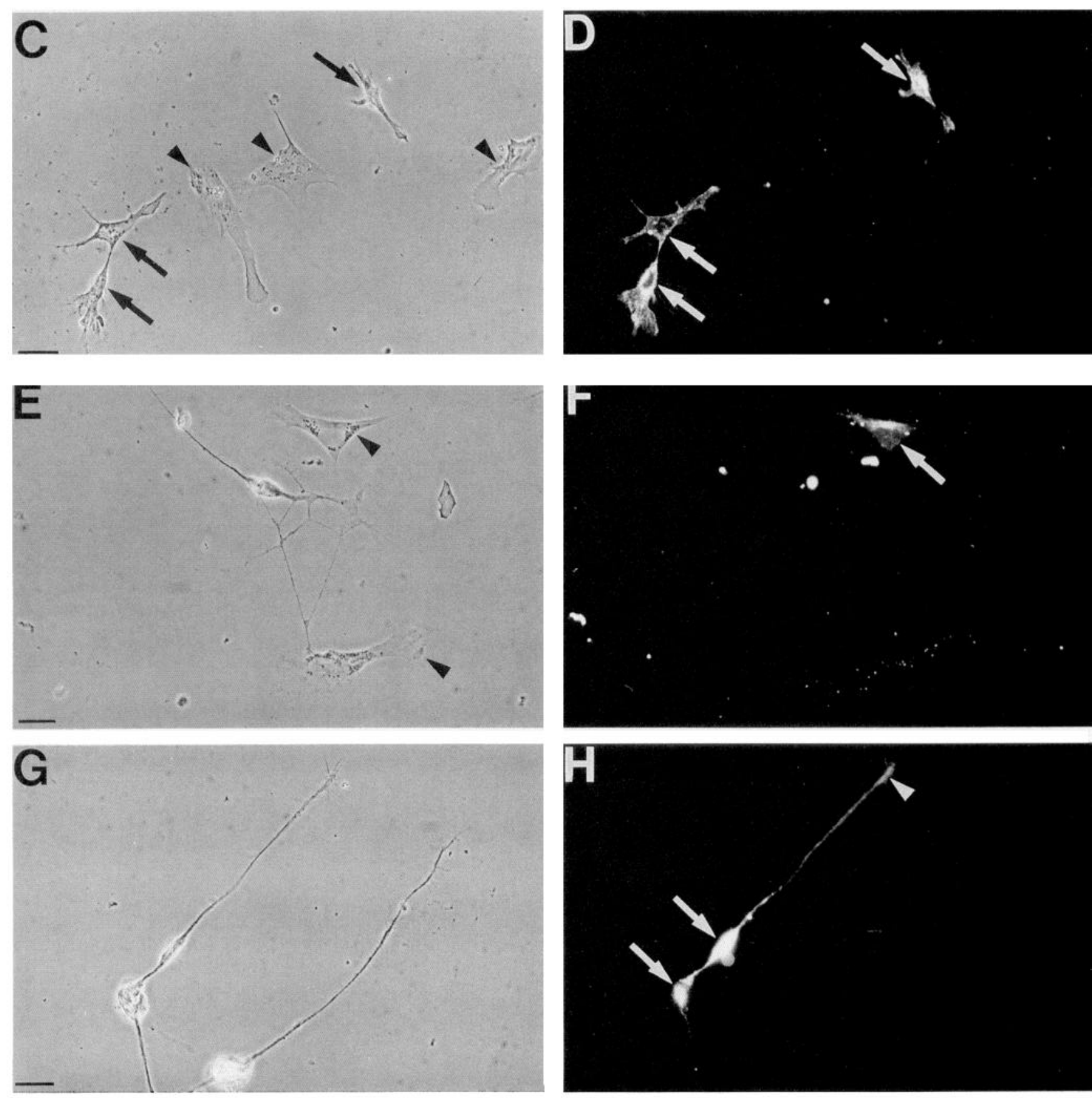
Table 1. General behavior of motor growth cones

\begin{tabular}{lllll} 
& \multicolumn{2}{l}{ Avoidance } & \\
\cline { 2 - 3 } $\begin{array}{l}\text { Orthog- } \\
\text { Onal } \\
\text { interaction }\end{array}$ & $\begin{array}{l}\text { Affinity } \\
\text { ing }\end{array}$ & $\begin{array}{l}\text { Turning } \\
\text { away }\end{array}$ & $\begin{array}{l}\text { Retrac- } \\
\text { tion }\end{array}$ & $\begin{array}{l}\text { Advance } \\
\text { onto cell }\end{array}$ \\
\hline $\begin{array}{l}\text { Posterior: } \\
\quad \text { Perpendicular (6) }\end{array}$ & 5 & 0 & 1 & 0 \\
$\quad 0$ & 4 & 0 & 0 \\
$\begin{array}{l}\text { Oblique (4) } \\
\begin{array}{l}\text { Anterior: } \\
\quad \text { Perpendicular (6) }\end{array}\end{array}$ & 0 & 0 & 0 & 6 \\
$\quad$ Oblique (4) & 0 & 0 & 0 & 4
\end{tabular}

Data show responses of motor growth cones to contact with sclerotome cells. In all cases motor growth cones avoided posterior cells but advanced onto anterior cells. Numbers indicate cases observed.

\section{Results}

\section{Identification of cells in vitro}

To make valid comparisons of growth cone interactions with sclerotome cells, the identity of the cells must be known. The identity of sclerotome subpopulations was assured by isolating only small aliquots of cells from dissected preparations. In these preparations, the borders between somites and the fissure between sclerotome halves are distinct landmarks (Fig. 1). We used these landmarks, together with precisely sized and polished micropipettes, to remove small groups of cells selectively from either the anterior or the posterior sclerotome.

We verified the selectivity of the isolations in preliminary experiments using immunocytochemical and lectin staining of sclerotome cultures. We found that cultures derived from the posterior sclerotome were homogeneous. All the cells in posterior cultures expressed a selective markcr for postcrior sclcrotome cells in vitro, PNA binding sites (Fig. 2B; Stern et al., 1986). PNA binding was not detected in anterior cultures (not shown). In contrast, we found that cultures derived from the anterior sclerotome were heterogeneous. Anterior cultures contained two cell populations. One population (approximately 10$30 \%$ of the cells) was composed of highly motile and filopodial cells that were phase bright. This population was reactive with the HNK-1 monoclonal antibody (Fig. $2 C, D$ ). These cells are therefore neural crest cells, which are known to invade the anterior somite preferentially (Rickman et al., 1985; Loring and Erickson, 1986). A second population was composed of less motile cells with a flattened, fibroblastic morphology. These cells were not reactive with the HNK-1 antibody and were considered to be anterior sclerotome cells. HNK-1-positive cells were not detected in posterior sclerotome cultures (not shown). Since PNA-positive cells were only detected in posterior cultures and

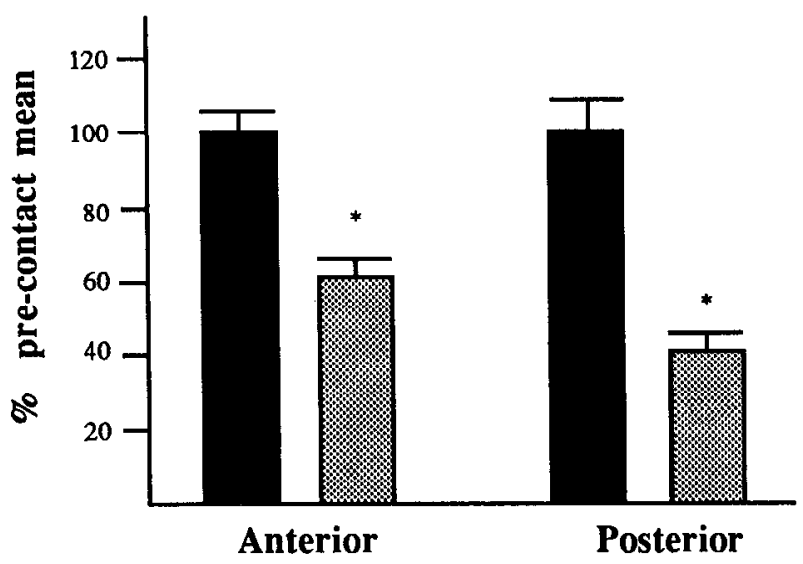

Figure 3. Relative growth rates before and after stable filopodial contact in perpendicular interactions. Mean relative rates of growth cone advance before (solid bars) and after (shaded bars) establishing stable filopodial contact with either anterior (left) or posterior (right) sclerotome cells. The rate of growth cone advance decreased significantly after contact regardless of the cell type. Asterisks indicate $p<0.05$ using the paired Student's $t$ test. Error bars indicate SEM.

HNK-1-positive cells were only detected in anterior cultures, we conclude that the isolation was effectively selective.

Since cultures derived from ventral spinal cord contain a variety of cell types, we used nontoxic lipophilic fluorescent dyes (Honig and Hume, 1986) to identify sclerotome cells and motor neurons unequivocally in cocultures. Sclerotome cells labeled with the green fluorescent lipophilic dye DiO were clearly distinct from morphologically similar but unlabeled spinal cord cells (Fig. $2 E, F$ ). Similarly, the red fluorescent lipophilic dye Dil clearly distinguished motor neurons labeled by spinal nerve injection from unlabeled cells (Fig. $2 G, H$ ). The unlabeled cells made up approximately $75 \%$ of the cells in ventral spinal cord cultures and are presumably interneurons, glia, and motor neurons that escaped labeling.

\section{General behavior of motor growth cones and sclerotome cells}

We found that motor growth cones respond specifically to each sclerotome cell type (Table 1). Motor growth cones invariably avoided posterior sclerotome cells. We observed two general types of avoidance behavior, branching and turning. The type of avoidance behavior correlated with the angle of approach. In most perpendicular interactions, where both sides of the growth cone contacted the cell, growth cones avoided the posterior cells by branching orthogonal to the initial direction of growth. In oblique interactions, where filopodia on only one side of the growth cone contacted the posterior cell, growth cones turned to avoid the posterior cell. In no case did a motor growth cone

Figure 2. Identification of sclerotome cells and motor growth cones in vitro. $A$ and $B$, Posterior sclerotome cultures are homogeneous. $A$, Phasecontrast image showing cells. $B$, PNA binding in the same field. Note that all the cells in these cultures selectively bind PNA to some extent, although cells that are less spread (arrows) tend to stain more intensely, as do cell fragments (arrowheads). This culture was also labeled with HNK-1 to identify neural crest cells; none were detected (not shown). $C$ and $D$, Anterior sclerotome cultures are heterogeneous. $C$, Phase-contrast image reveals two distinct cell types: the flattened cells (arrowheads) and filopodial cells (arrows) with phasc-bright nuclci. Filopodial cells such as thcse were common in anterior cultures, were absent from posterior cultures, and were highly motile. $D$, The filopodial cells (arrows) express the HNK-1 antigen and are therefore neural crest cells, whereas the flattened cells are not reactive and are therefore anterior sclerotome cells. This culture was also stained with PNA and no PNA-positive cells were detected (not shown). $E$ and $F$, Identification of sclerotome cells in spinal cord/sclerotome cocultures. $E$, Two essentially indistinguishable flattened cells (arrowheads) are present in this field along with an unidentified neuron. $F$, The upper cell (arrow) is distinguished as a sclerotome cell by DiO fluorescence. $G$ and $H$, Identification of motor neurons in spinal cord/sclerotome cocultures. DiI labeling identifies two cells in this field as motor neurons (arrows in $H$ ). Also note that dye labeling extends into the growth cone (arrowhead). Scale bars, $20 \mu \mathrm{m}$. 

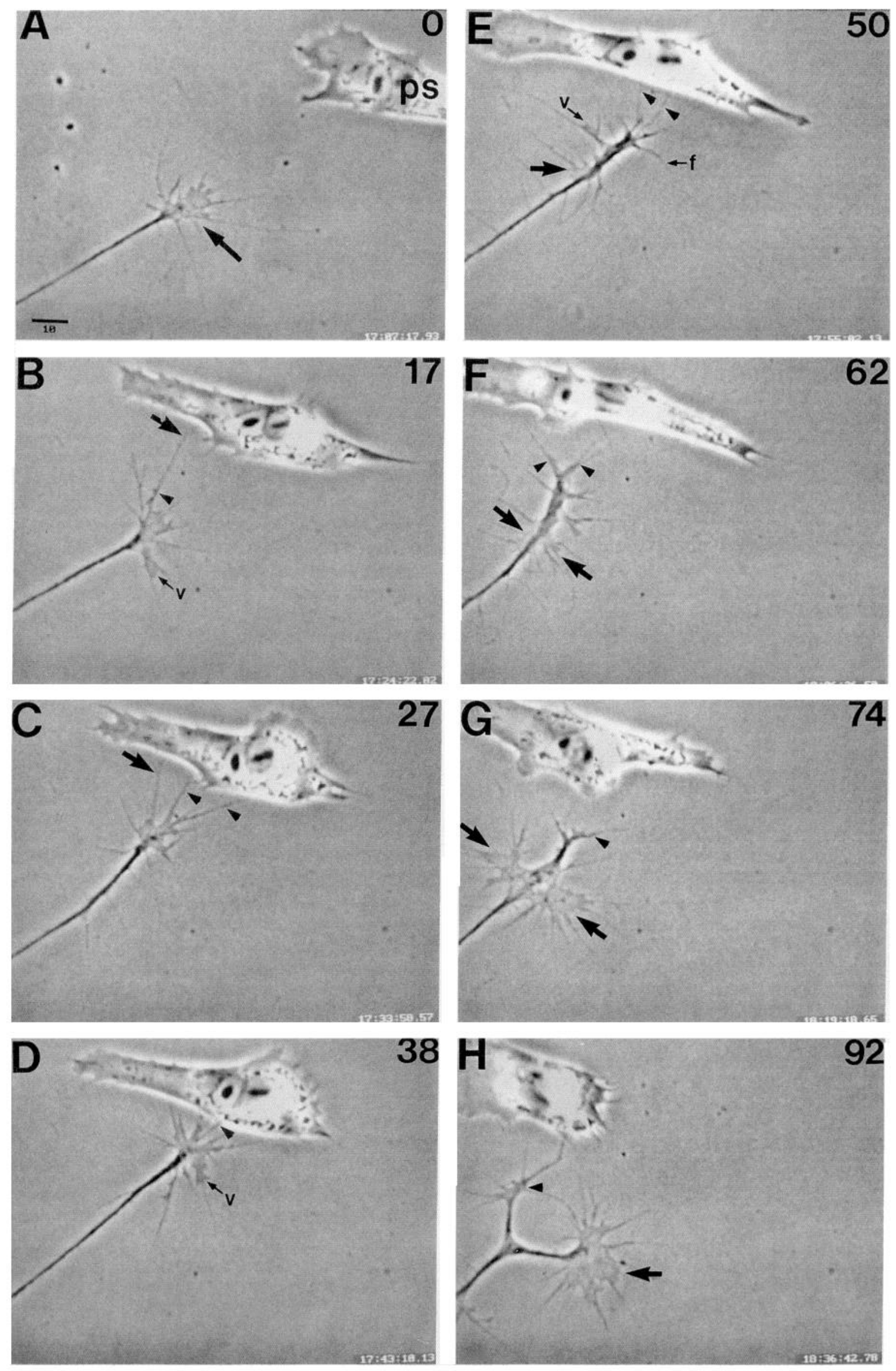
advance onto a posterior sclerotome cell. In contrast, motor growth cones exhibit a selective affinity for anterior sclerotome cells. In all cases, the growth cones either completely or partially grew on to the anterior cell. In most cases ( 8 of 10$)$, motor growth cones left the laminin substratum and extended onto the cell. In all cases of perpendicular interaction, the growth cones remained on the cell for the remainder of the recording period (up to $180 \mathrm{~min}$ ). These results show that motor growth cones behave in vitro as they do in vivo: they avoid posterior sclerotome cells but advance onto anterior cells.

We also found a second generalized response to contact: motor growth cones always decreased their rate of advance upon contacting either cell type (Fig. 3). Prior to filopodial contact, motor growth cones advanced at steady rates that averaged $89.6 \mu \mathrm{m} /$ hr. During the $10 \mathrm{~min}$ after stable filopodial contact, motor growth cones slowed to approximately $40-60 \%$ of their precontact advance rate in perpendicular interactions with either anterior or posterior sclerotome cells. These results suggest that contact-dependent changes in growth rates do not predict subsequent behavior.

Sclerotome cells also responded to contact by motor growth cones but their responses were similar regardless of their cell type (Table 2). Most anterior and posterior sclerotome cells exhibited both increased motility and local condensation of cell processes (e.g., Fig. 12E) following contact with motor growth cones. However, some cells responded to contact with only moderate increases in ruffling activity and two cells showed no detectable response. Since changes in sclerotome cell motility appear to be independent of the cell type, it is unlikely that the specific responses of motor growth cones to each cell type depend on the bchavioral responses of the sclerotome cells.

\section{Perpendicular interactions with posterior sclerotome cells}

When motor growth cones directly confronted posterior sclerotome cells, their typical response (five of six cases) was to avoid the cell by branching orthogonal to the original direction of growth. Branch formation was always preceded by a stereotyped series of changes in growth cone motility (Fig. 4). Prior to filopodial contact with a posterior cell, motor growth cones advanced steadily across the laminin substrate by protruding broad veils between adjacent filopodia. Once stable filopodial contact was established, only very small, abortive veils formed along the contacting filopodia. In contrast, the noncontacting filopodia continued to support the formation of veils. These veils were much broader and were longer lived than those that formed between contacting filopodia (Fig. 4B). Contact with posterior cells thus inhibited veil protrusion locally. As morc filopodia

\begin{tabular}{|c|c|c|c|}
\hline $\begin{array}{l}\text { Cell type: } \\
\text { interaction }\end{array}$ & Quiescent & $\begin{array}{l}\text { Increased } \\
\text { ruffling }\end{array}$ & $\begin{array}{l}\text { Increased } \\
\text { motility and } \\
\text { condensation }\end{array}$ \\
\hline \multicolumn{4}{|l|}{ Posterior: } \\
\hline Perpendicular (6) & 0 & 2 & 4 \\
\hline Oblique (4) & 1 & 1 & 2 \\
\hline \multicolumn{4}{|l|}{ Anterior: } \\
\hline Perpendicular (6) & 0 & 4 & 2 \\
\hline Oblique (4) & 1 & 0 & 3 \\
\hline
\end{tabular}

Data show rcsponscs of sclcrotomc cells to contact with motor growth concs. Most sclerotome cells, regardless of cell type, exhibit increased motility and condensation of cell processes upon contact. Numbers indicate cases observed.

made stable contact with the cell, the inhibition of veil protrusion along contacting filopodia resulted in a significant ( $p<$ 0.002 ) decrease in the overall surface area in four of the five growth cones analyzed (Figs. $4 C, 5 A$ ). Since the inhibition of veil protrusion slows but does not fully impede growth cone advance, the leading edge of the growth cone eventually contacts the cell. Following contact, the leading edge of the growth cone retracts from the cell while maintaining filopodial contacts and continuing to protrude new veils and filopodia (Fig. 4E). Protrusive activity thus continues following full contact with the cell. As the growth cone retracts somewhat from the cell, filopodia and veils also protrude from the more proximal portions of the neurite that had previously been consolidated and quiescent (Fig. $4 E, F$ ). These secondary sites of activity produce two new growth cones that extend orthogonal to the original direction of growth, despite the continued protrusive activity in the more distal growth cone (Fig. 4G). Eventually, the distal growth cone is withdrawn, one of the two orthogonally directed growth cones dominates, and the overall direction of neurite extension is altered by nearly $90^{\circ}$. At no time did we observe a motor growth cone that ceased to protrude new processes after contacting a posterior sclerotome cell.

To determine if contact with posterior cells inhibits motility generally, we analyzed two additional aspects of protrusive activity: the rate of veil protrusion and the number of filopodia produced. We found that contact with posterior cells does not significantly alter the rate of veil protrusion (Fig. $5 B$ ). Thus, although fewer and obviously smaller veils were produced following contact, those veils that do form progress at normal rates. We also found that contact with posterior cells does not significantly alter the number of filopodia protruded (Fig. $5 C$ ). These

\footnotetext{
Figure 4. Video sequence of a typical perpendicular interaction with a posterior sclerotome cell. Approximate elapsed time (in minutes) is indicated at the top right of each frame. $A$, Motor growth cone (arrow) approaching a posterior sclerotome cell ( $p s$ ). The cell is moving slowly to the left. $B$, The growth cone makes filopodial contact with the cell (arrow). Although this contacting process is prominent and long lasting, it does not support the progression of broad veils $(v)$ as do noncontacting processes. Small, abortive veils (arrowhead) are frequently seen along contacting filopodia. $C$, The initial filopodial contact (arrow) is still maintained and others (arrowheads) have been established. Veils do not progress well along contacting filopodia; the overall surface area of the growth cone is reduced and the rate of advance slows. $D$, The growth cone contacts the cell extensively with both filopodia and small veils (arrowhead). Note a much larger veil $(v)$ directed along noncontacting filopodia. $E$, After the leading edge of the growth cone contacts the cell, veils are retracted, although filopodial contacts (arrowheads) remain. The growth cone remains active throughout the interaction, producing new filopodia $(f)$ and veils $(v)$. Also note that the more proximal neurite (arrow) is less consolidated and has begun to produce both veils and filopodia. $F$, As the leading edge of the growth cone (arrowheads) advances toward the cell again, the proximal neurite has lost its dark consolidated appearance and secondary sites of filopodial and veil activity develop on both sides of the neurite (arrows). $G$, The leading edge of the growth cone (arrowhead) retracts away from the cell again as the proximal, secondary sites of activity produce two growth cones (arrows) directed orthogonal to the original direction of growth. $H$. The secondary growth cone on the left (arrowhead) contacts the cell, is reduced in size, and eventually retracts, whereas the growth cone on the right (arrow) continues growing, accomplishing a near right angle turn. Scale bar, $10 \mu \mathrm{m}$.
} 


\section{A. Surface area of growth cone}

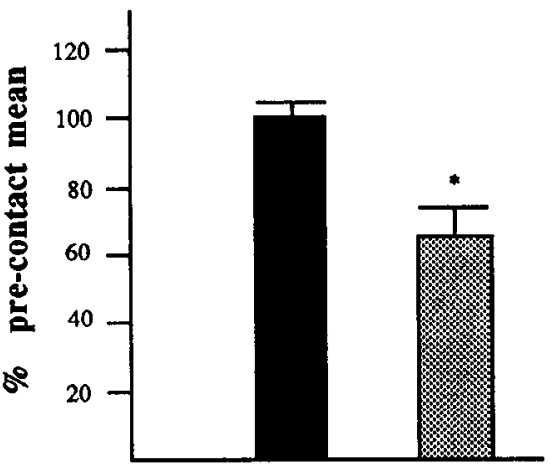

\section{B. Rate of veil protrusion}

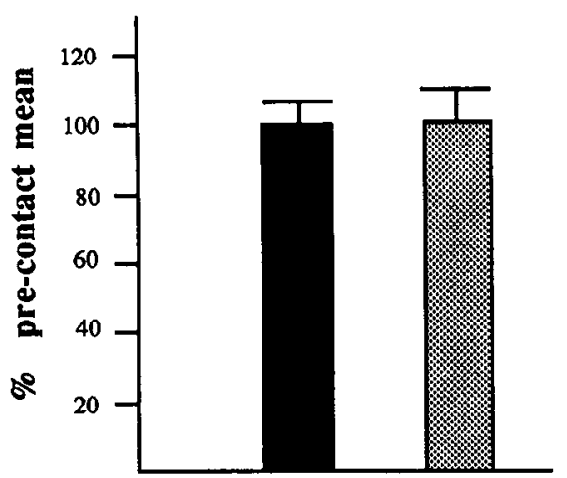

\section{Number of filopodia}

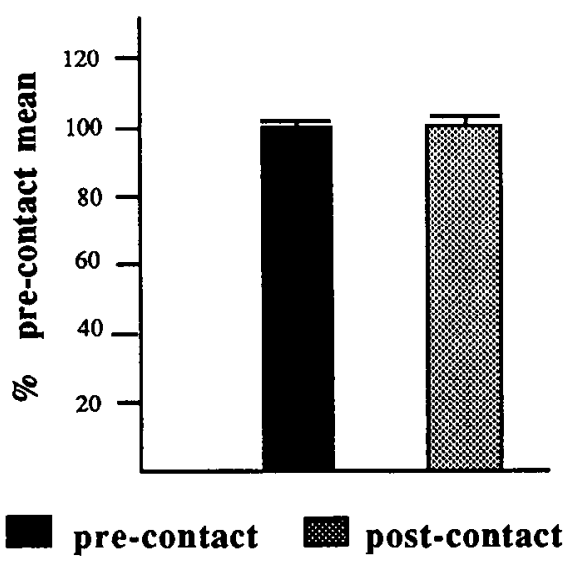

Figure 5. Contact-dependent changes in growth cone motility during perpendicular interactions with posterior sclerotome. $A$, Mean relative surface area of growth cones before (solid bar) and after (shaded bar) the establishment of stable filopodial contact. Note that in four of five cases tested, the mean growth cone surface area decreased significantly $(p<0.002)$ during the 10 min postcontact measurement period when compared to the precontact mean. $B$, Mean relative rates of veil protrusion before (solid bar) and after (shaded bar) the establishment of stable filopodial contact. The mean rate of veil protrusion during the postcontact period was not significantly different from the precontact mean in any of the five cases. $C$, Mean relative number of filopodia before (solid bar) and after (shaded bar) the establishment of stable filopodial contact. The mean number of filopodia during the postcontact period was not significantly different from the precontact mean in any of the five cases. Asterisks indicate significant differences from precon- results suggest that contact with posterior cells selectively inhibits the number and/or size of veils protruded without affecting either the number of filopodia protruded or the rate of veil protrusion.

Although none of the motor growth cones we observed lost the capacity to protrude new processes, in one case we did observe the collapse of the most distal portion of the growth cone as secondary sites of activity produced two orthogonally directed growth cones (Fig. 6). During this interaction, we observed the same stereotyped sequence of changes in motility described above: the rate of advance slowed, only small abortive veils formed along contacting filopodia, the distal growth cone retracted after the leading edge contacted the cell, and secondary sites of activity produced two new growth cones from the once consolidated neurite. Although this interaction was largely similar to the others, it differed in two ways. First, the surface area of the growth cone was not significantly reduced during the first 10 min after stable filopodial contact. Second, the distal portion of the growth cone subsequently collapsed and failed to protrude any new processes (Fig. $6 G, H$ ). The distal growth cone collapsed only after the leading edge made extensive contact with the cell and after the loss of consolidation in the more proximal neurite. This loss of motility was highly local since protrusive activity continued in the proximal neurite despite the loss of activity and the collapse of distal growth cone structure.

While none of the motor growth cones we observed interacting with posterior sclerotome cells collapsed completely, we did observe complete motor growth cone collapse in some circumstances. For example, Figure 7 illustrates a motor growth cone that collapsed and lost the capacity to protrude new processes after contacting a small fascicle of neurites. This interaction shows that motor growth cones can collapse completely under our culture conditions.

\section{Oblique interactions with posterior sclerotome cells}

Analysis of motor growth cone behavior in oblique interactions with posterior cells strongly suggests that contact inhibits veil protrusion only very locally (Fig. 8). Only those filopodia that contact posterior cells fail to support veil protrusion. In contrast, broad veils form between noncontacting filopodia on the other side of the growth cone (Fig. $8 C, F$ ). The local inhibition of veil formation results in an asymmetry in the distribution of growth cone surface area with significantly more of the growth cone surface area directed away from the posterior cell (Figs. $8 F, 9 A$ ). In all cases observed, subsequent growth was biased in the direction of continued veil protrusion and the growth cones turned away from the posterior cell.

To determine if growth cone turning depended on an asymmetry in either filopodial protrusion or retention, we analyzed these variables in oblique interactions. When we compared the side of the growth cone contacting the cell to the noncontacting side, we found no significant asymmetry in the distribution of filopodia (Fig. 9B). Moreover, those filopodia that contacted posterior cells were retained significantly longcr than those that contacted only the laminin substrate (Fig. 9C). Thus, motor growth cones turned away from posterior cells in the absence

tact means; all statistical comparisons were made on individual growth cones using the paired Student's $t$ test. Error bars indicate SEM. 
of an asymmetry in filopodial distribution and in spite of more persistent contacts with the cell.

\section{Perpendicular interactions with anterior sclerotome cells}

When motor growth cones directly confronted anterior sclerotomc cclls, thcy invariably advanced onto these cells. This response, however, was not immediate: it followed a protracted series of localized protrusive events that eventually resulted in the growth cone slowly leaving the laminin substrate in favor of the anterior cell surface (Fig. 10). Once on the cell, the growth cone typically continued to advance only very slowly, remaining on the cell for the duration of the recording session (up to 180 min).

After initial filopodial contact with an anterior cell, the entire growth cone increased its protrusion of both veils and filopodia. In all five cases analyzed, filopodial contact stimulated a net increase in veil protrusion, as evidenced by a significant increase in growth cone surface area (Fig. $11 A$ ). However, we did not detect any change in the rate of veil protrusion (Fig. $11 B$ ). Thus, contact with anterior cells stimulates the protrusion of more and/or larger veils or enhances the stability of veils without altering the rate of veil advance. Moreover, contact with anterior cells also stimulated filopodial protrusion. Contact significantly increased the number of filopodia protruded in all five cases analyzed (Fig. $11 C$ ). Furthermore, the stimulation of protrusive activity was not restricted solely to the site of contact. More proximal portions of the growth cone also dramatically increase in complexity following only local contact (compare Fig. 10B,C). Thus, filopodial contact with anterior sclerotome cells stimulates a general increase in protrusive activity: contact results in a net increase in the extension of veils and filopodia both locally and at sites distant from the site of contact.

Individual processes that extended onto anterior cells exhibited characteristic cycles of protrusion followed by localized consolidation. Both veils and filopodia often thickened to form small branches that, in turn, protruded new processes onto the cell surface. These subsidiary branches often became transiently complex as they explored the cell, simultaneously sampling both the cell surface and the adjacent substrate (Fig. 10F, lower branch). Eventually, these branches became simplified and consolidated: they assumed the phase-dark appearance of a neurite (Fig. 10G, lower branch). This cycle of events was reiterated by other processes as they extend onto the anterior cell (Fig. 10G,H, upper branch). These processes become consolidated despite the fact that the body of the growth cone remains spread on the laminin substrate. Eventually, the body of the growth cone on the substrate becomes consolidated into the nascent neurite as the more distal region forms a growth cone that very slowly spreads along the long axis of the cell (Fig. $10 H-J$ ). Although this growth cone continues to protrude many new processes that sample the laminin substrate, it remains on the cell. While motor growth cones did not leave anterior cells for the laminin substrate, they would presumably continue growing if another anterior cell was in filopodial range.

These results demonstrate that motor growth cones have a selective affinity for anterior sclerotome cells, preferring the surfaces of these cells to the laminin substratum. Moreover, these results show that initial contact with anterior cells stimulates protrusive activity and suggest that prolonged contact may enhance neurite consolidation. Our results are somewhat reminiscent of those of Letourneau and colleagues, who found that sensory growth cones exhibit a similar selective affinity for
Schwann cells (Letourneau et al., 1990, 1991). However, sensory growth cones rapidly advanced onto Schwann cells and it is unclear whether contact with Schwann cells stimulated either protrusive activity or neurite consolidation as we have documented here.

\section{Oblique interactions with anterior sclerotome cells}

Oblique interactions with anterior sclerotome cells were, in many ways, similar to perpendicular interactions. In all cases observed, growth cones extended processes (both veils and filopodia) onto anterior cells that remained for the duration of the recording period. The sequence of responses to contact was also similar. As in perpendicular interactions, oblique contact first resulted in a generalized increase in protrusive activity (e.g., Fig. $12 C$ ). In fact, contact stimulated protrusive activity even in consolidated regions of the neurite. For example, a flurry of protrusion resulted when the consolidated portion of the neurite was contacted by an anterior cell (Fig. 12F). After more prolonged contact, individual processes that extended onto the cell exhibited similar cycles of protrusion followed by consolidations (Fig. $12 B, E, G, J$ ). The consolidation of growth cone processes was, however, more clearly associated with local contact. For example, we observed dramatic, albeit transient, consolidation on the cell-contacting side of the growth cone after repeated filopodial contact (Fig. 12B).

Analysis of oblique interactions also emphasizes the selective affinity of motor growth cones for anterior cells. In all cases examined, growth cones sustained contact with the anterior cell despite extensive growth of other portions of the growth cone that contact the laminin substrate. Typically, most of the processes that did not contact the cell were eventually withdrawn (Fig. 12E-J).

Quantitative analysis of oblique interactions indicates that protrusive activity is stimulated generally: the surface area protruded was similar on both sides of the growth cone (Fig. 13A). Moreover, after contact a similar number of filopodia were protruded on both sides of the growth cone (Fig. 13B). These results further confirm that contact with anterior cells stimulates protrusive activity generally rather than locally: although asymmetric contact increases both surface area and filopodial protrusion, it does so without producing a significant asymmetry in protrusive activity.

Finally, to determine if the direction of growth was correlated with filopodial retention, we compared filopodia that contacted the cell to those that contacted only the laminin substrate. Those filopodia that contact the anterior cell were not retained significantly longer than those that contacted only the substrate (Fig. $13 C$ ). Therefore, filopodial retention does not reliably indicate subsequent behavior.

\section{Discussion}

We have shown that motor growth cones avoid posterior sclerotome cells but advance onto anterior sclerotome cells in vitro. This differential pattern of behavior was highly consistent and mirrors the behavior of motor growth cones in vivo. These results thus validate our approach to modeling motor axon segmentation in vitro. Moreover, these results strongly suggest that the specific changes in growth cone motility that we have documented contribute significantly to the preferential advance of motor axons into the anterior sclerotome in the embryo. 

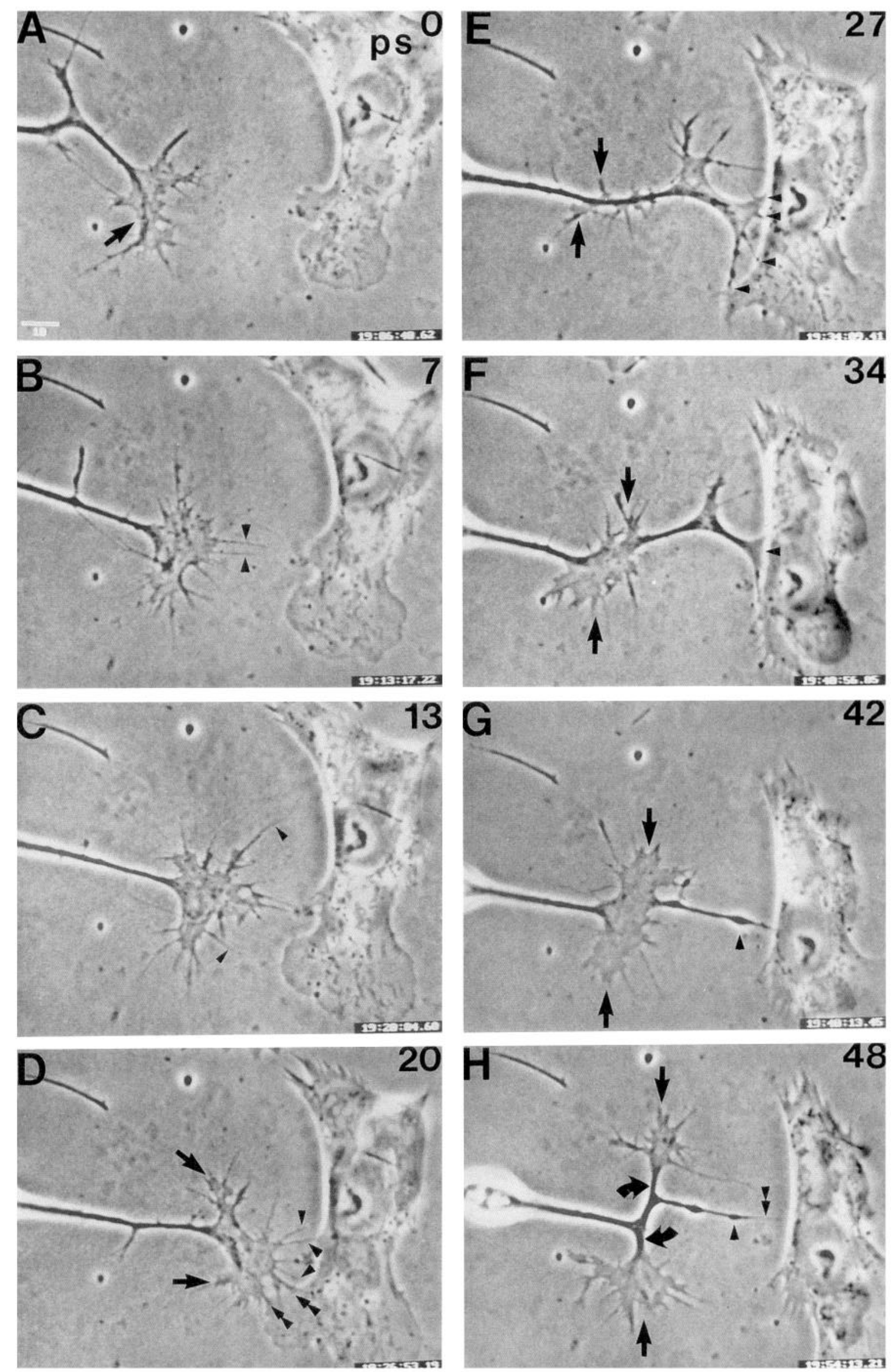

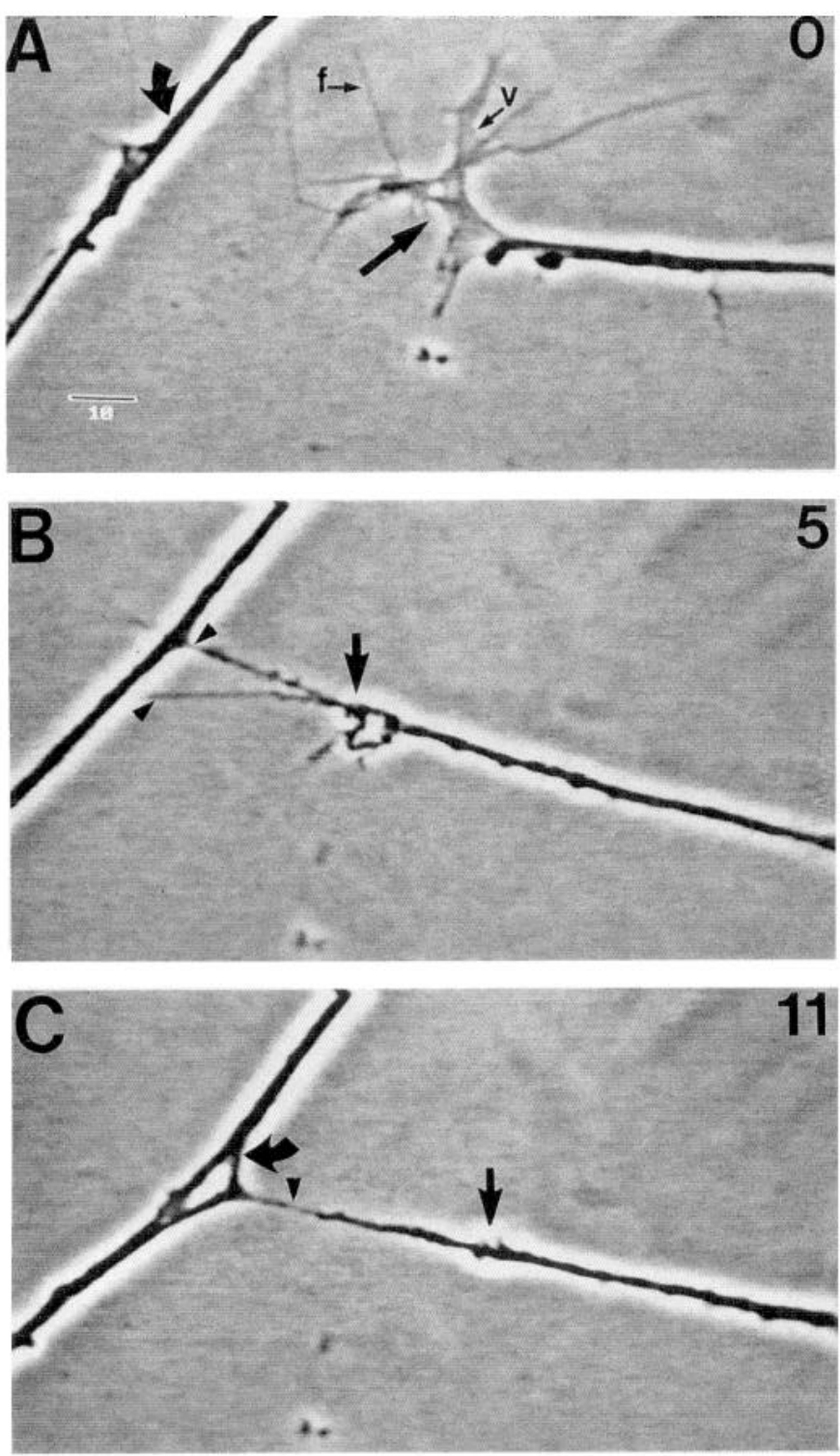

Figure 7. Video sequence of a motor growth cone collapsing upon contact with neurites. Approximate elapsed time (in minutes) is indicated at the top right of each frame. A, A motor growth cone (straight arrow) approaches a small fascicle of neurites (curved arrow). Note the active veils $(v)$ and filopodia $(f)$. B, After processes contact the fascicle (arrowheads), the veiled structure collapses (arrow) and retracts away from the fascicle. $C$, The collapsed motor growth cone (straight arrow)

\section{Inhibition and stimulation of growth cone motility by sclerotome cells}

Contact with different sclerotome cell types had differential effects on motor growth cone motility. Contact with anterior cells elicited a generalized net increase in protrusive activity. Both the number of filopodia and the surface area of the growth cone increased on contact. The increased protrusion was not localized solely to the site of contact: even when contact was local, the entire growth cone increased in complexity. In contrast, contact with posterior cells specifically inhibited the extension of veils along contacting filopodia. This inhibition was specific to veils: contact failed to alter the number of filopodia. Moreover, the racnnnse was highly localized: veil extension was inhibited only at sites of contact.

Contact with different sclerotome cell types also differentially affects neurite consolidation. Contact with anterior cells elicited a localized thickening of contacting processes (both veils and filopodia). Individual processes often took on the appearance of a consolidated neurite even before the main body of the growth cone consolidated. In contrast, extensive contact with posterior cells elicited a loss of consolidation in the proximal neurite. This response required sustained contact along the leading edge of the growth cone. Moreover, consolidation was lost at sites quite distant from the site of contact.

The behavior of filopodia also differed depending on the cell type contacted. Filopodia that contacted posterior cells were retained longer than those that contacted the laminin substratum. In contrast, filopodia that contacted anterior cells were not retained longer than substratum contacts. Thus, motor growth cones turned away from posterior cells despite filopodial contacts of longer duration with these cells. Moreover, motor growth cones turned onto anterior cells in the absence of an asymmetry in the duration of contact.

\section{Contact-dependent mechanisms of growth cone guidance}

The avoidance of posterior sclerotome cells in vitro is mediated by a mechanism that appears to be distinct from growth cone collapse, at least at the level of growth cone behavior. Upon contacting posterior cells, motor growth cones exhibited two

has lost its motile capabilities but retains a fine process (arrowhead) connected to the fascicle; it retracts further, exerting obvious tension on the fascicle (curved arrow). This motor growth cone failed to produce any new processes for at least $10 \mathrm{~min}$ after collapse. This sequence shows that motor growth cones can collapse completely in these cultures. Scale bar, $10 \mu \mathrm{m}$.

\footnotetext{
Figure 6. Video sequence of a perpendicular interaction with a posterior sclerotome cell. This sequence shows an atypical, partial collapse of the growth cone. Approximate elapsed time (in minutes) is indicated at the top right of each frame. A, Motor growth cone (arrow) approaching a posterior sclerotome cell $(p s)$. B. The growth cone establishes filopodial contact via very fine extensions of the two prominent, forward-directed filopodia (arrowheads). These filopodia are long lived (compare $C$ ) but do not support veil progression. $C$, The growth cone slows its forward progress as fine extensions from more filopodia (arrowheads) make stable contacts. $D$, Although many forward directed filopodia (single arrowheads) contact the cell, broad veils do not form between these filopodia. Veil protrusion is more pronounced at sites removed from contact points (arrows). Small veils (double arrowheads) along the lower leading edge of the growth cone also contact the cell. $E$, As the growth cone makes extensive frontal contact (arrowheads) with the cell, the size of the flattened portion of the growth cone decreases dramatically. Also note the concomitant increase in protrusive activity at secondary sites (arrows) along the proximal neurite in regions that had previously been consolidated (compare $D$ ). $F$, The distal growth cone remains in contact with the cell (arrowhead). Although the size of the distal growth cone has decreased further, it remains active. The protrusive activity in the proximal neurite has resulted in a loss of consolidation as two new growth cones (arrows) begin to form. $G$, The distal growth cone (arrowhead) collapses and begins to retract as motile activity in this portion of the neurite ceases. The secondary protrusive sites in the proximal neurite produce two growth cones (arrows) directed orthogonal to the original direction of growth. $H$, The distal growth cone (single arrowhead) remains quiescent and retracts further, leaving a fine process (double arrowhead) connected to the cell. The secondary sites of activity have become consolidated (curved arrows) as the two orthogonally directed growth cones (straight arrows) progress parallel to the cell. Scale bar, $10 \mu \mathrm{m}$.
} 

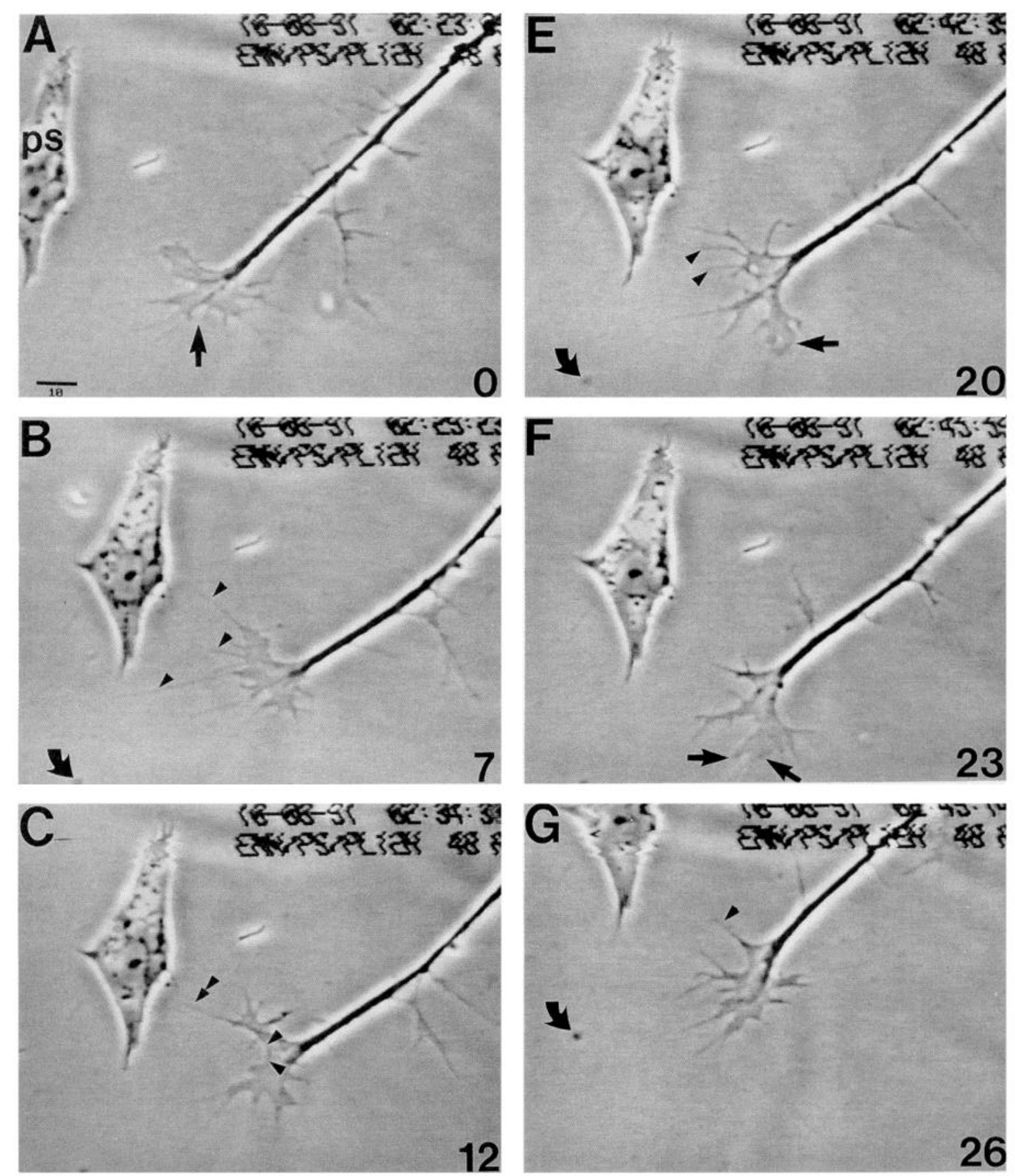

D 26-202-21 re:32:50

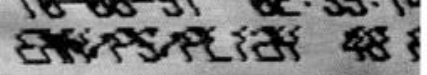
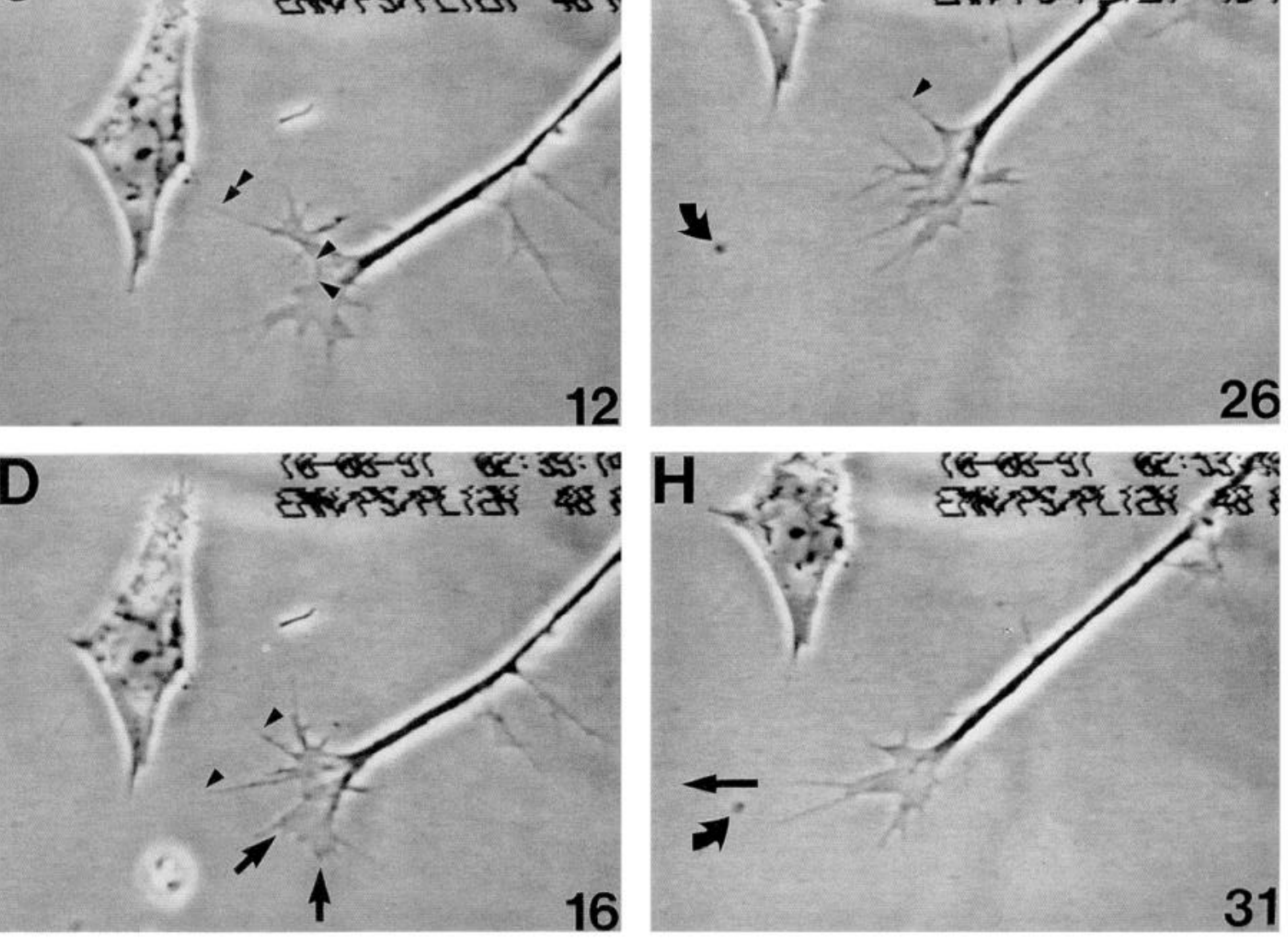
distinct types of avoidance behavior, both of which were initiated by a local inhibition of veil protrusion. First, in perpendicular confrontations, veils failed to progress along contacting filopodia and retracted from the cell, while the growth cone continued to protrude new processes. The growth cone then branched following the resumption of protrusive activity in the previously consolidated neurite. Second, in oblique confrontations, motor growth cones turned away from posterior cells following a local inhibition of veil protrusion on the contacting side of the growth cone. Thus, avoidance of posterior cells is due to a highly localized, negative influence on the protrusion or stabilization of veils.

In no case did contact with posterior cells result in the complete loss of both growth cone motility and structure that characterizes growth cone collapse (Kapfhammer and Raper, 1987a; Bandtlow et al., 1990; Cox et al., 1990; Johnston and Gooday, 1991). Since we did observe motor growth cone collapse after contact with other neurites, differences in culture conditions or intrinsic differences in neural populations clearly cannot account for the lack of collapse following contact with posterior sclerotome cells.

The avoidance behavior we have documented, while behaviorally distinct, shares several important features with growth cone collapse. For example, both behaviors require the direct contact of cell membranes. In both cases, contact reduces protrusive activity, albeit globally in the case of collapse. Moreover, long-lived filopodial contacts characterize interactions with both posterior cells and cells that induce collapse (Kapfhammer and Raper, 1987a; Bandtlow et al., 1990; Johnston and Goody, 1991). Furthermore, in one interaction, we observed the local collapse of a portion of a motor growth cone. These shared features suggest a common underlying mechanism. It seems likely that

$\longrightarrow$

Figure 9. Contact-dependent changes in growth cone motility during oblique interactions with posterior sclerotome. This figure illustrates a side-to-side comparison of interactions in which only one side of the growth cone contacts the posterior cell. In all graphs, the cell-contacting side (light bar) is compared to the noncontacting side (dark bar) during a 20-30 min measurement period after the establishment of stable filopodial contact. $A$, The comparison of mean growth cone surface area shows a significant asymmetry in the distribution of surface area with more of the growth cone surface directed toward the noncontacting side. $B$, Comparison of the mean number of filopodia protruded on either side of the growth cone shows no significant asymmetry in the distribution of filopodia. $C$, Comparison of the mean retention time of cellcontacting filopodia and noncontacting filopodia shows that filopodia that contacted posterior cells were retained significantly longer than those that contacted the substrate $(N=38)$. Asterisks indicate significant differences between means $(p<0.001)$ as judged by the Student's $t$ test. ErTor bars indicate SEM.

\section{A. Surface area of growth cone}

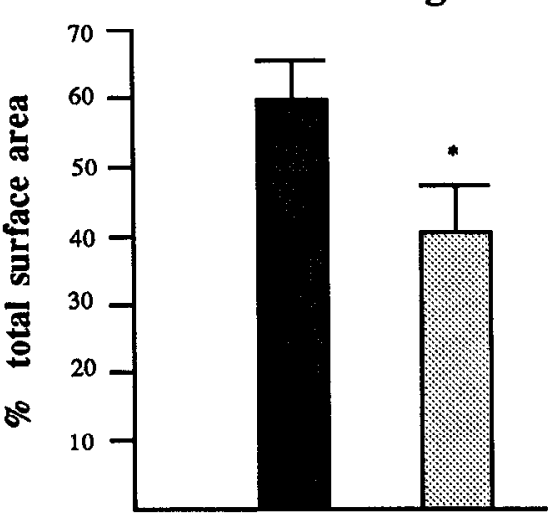

B. Number of filopodia

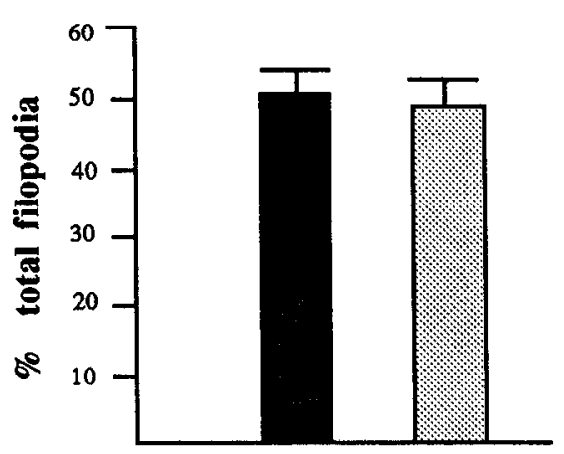

\section{Retention of filopodia}

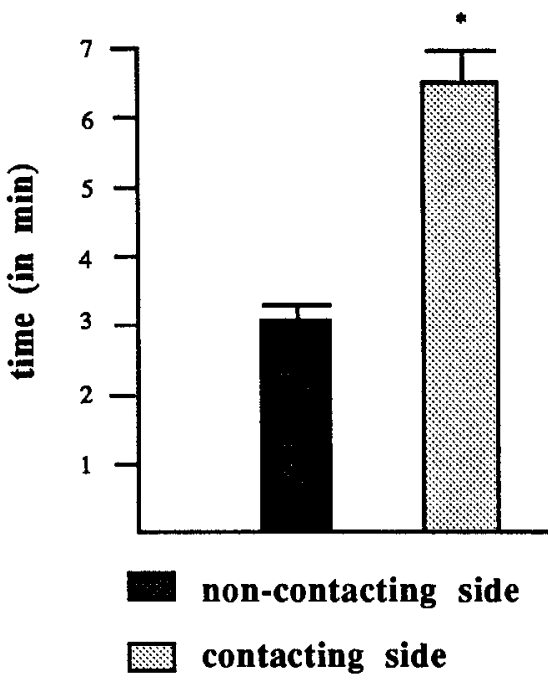

\footnotetext{
Figure 8. Video sequence of an oblique interaction with a posterior sclerotome cell. Approximate elapsed time (in minutes) is indicated at the lower right of each frame. Since the frame shifts during recording, a fixed point on the substrate (curved arrow) is indicated for orientation. $A$, A motor growth cone (arrow) approaches a posterior sclerotome cell $(p s)$ at an acute angle. Note the largely symmetrical distribution of the flattened portion of the growth cone prior to contact. $B$, On one side of the growth cone, fine extensions of at least three filopodia (arrowheads) contact the cell. $C$, The uppermost contacting filopodium (double arrowhead) is long lived (compare $B$ and $D$ ), whereas the lower two filopodia are withdrawn and the veils at their bases (single arrowheads) have retracted (compare $B$ ). $D$, An asymmetry in veil distribution develops as veils progress along noncontacting filopodia (arrows) but fail to progress along contacting filopodia (arrowheads). $E$, The growth cone continues to protrude new filopodia that contact the cell (arrowheads). Again, these contacting filopodia fail to support veil protrusion. Note the continued veil activity (arrow) on the noncontacting side of the growth cone. $F$, Several contacting filopodia have retracted (compare $E$ ) and no veil activity is directed toward the cell. In contrast, veils readily protrude along noncontacting filopodia (arrows) and the growth cone begins to turn in the direction of maintained veil activity. $G$, Although at least one contacting filopodium (arrowhead) is retained, the growth cone turns away from the cell. $H$, Finally, all contacting filopodia are retracted and the growth cone grows around the cell (direction indicated by arrow), avoiding any further contact. Scale bar, $10 \mu \mathrm{m}$.
} 
Figure 10. Video sequence tracing of a typical perpendicular interaction with an anterior sclerotome cell. All growth cone processes have been drawn in black for clarity. Approximate elapsed time (in minutes) is indicated at the top left of each frame. A, A motor growth cone (arrow) approaches an anterior sclerotome cell (as). $B$, Two filopodia (arrowheads) contact the cell and a veil (v) protrudes distally between them. The surface area of the growth cone has expanded. The cell responds by extending toward the growth cone (compare $A$ ). $C$, The growth cone has protruded processes onto the cell (arrow) and a thickened branch (arrowhead) has formed connecting these to the growth cone. Many other filopodia $(f)$ now contact the cell and the cell has elongated. $D$, The connccting branch (arrow) has thickened further as the cell retracts somewhat from the growth cone. The overall rate of growth cone advance has decreased. $E$, The branch (arrow) becomes more prominent as it progresses slowly along the lower edge of the cell. Small veils $(v)$ and filopodia $(f)$ explore the surface of the cell. Many filopodial contacts (arrowheads) on the upper part of the cell are long lived (compare $D$ ) and the surface area of the growth cone has expanded as veils extend along these filopodia. $F$, A branch of the growth cone (straight arrow) continues to grow slowly along the edge of the cell, protruding small veils $(v)$ and filopodia $(f)$. Note that this branch also forms a large, filopodial projection (curved arrow) onto the substrate that is subsequently retracted (compare $G$ ). Filopodia (e.g., arrowhead) also protrude past the upper edge of the cell, which is slowly elongating. $G$, The lower branch of the growth cone (arrow) becomes remarkably simpler as it grows along the long axis of the cell. Broad veils (arrowheads) advance onto the upper part of the cell and begin to align with its long axis. $H$, The veils on the upper part of the cell have consolidated into an upper branch (arrowhead), which turns along the long axis of the cell. The lower branch (straight arrow) continues to produce new processes (compare $G$ ) but remains on the cell. The proximal part of the growth gone (curved arrow) continues to protrude many veils (v) and filopodia $(f)$. I, The upper branch (arrowhead) has expanded remarkably as the former body of the growth cone (curved arrow in $H$ ) becomes consolidated. The lower branch (arrow) has become attenuated. $J$, The proximal portion of the growth cone (curved arrow) has consolidated further as processes contacting the substrate are resorbed in favor of those on the cell (compare $I$ ). Although both branches continue to protrude new processes, the growth cone progresses very slowly and remains on the cell. Scale bar, $10 \mu \mathrm{m}$.
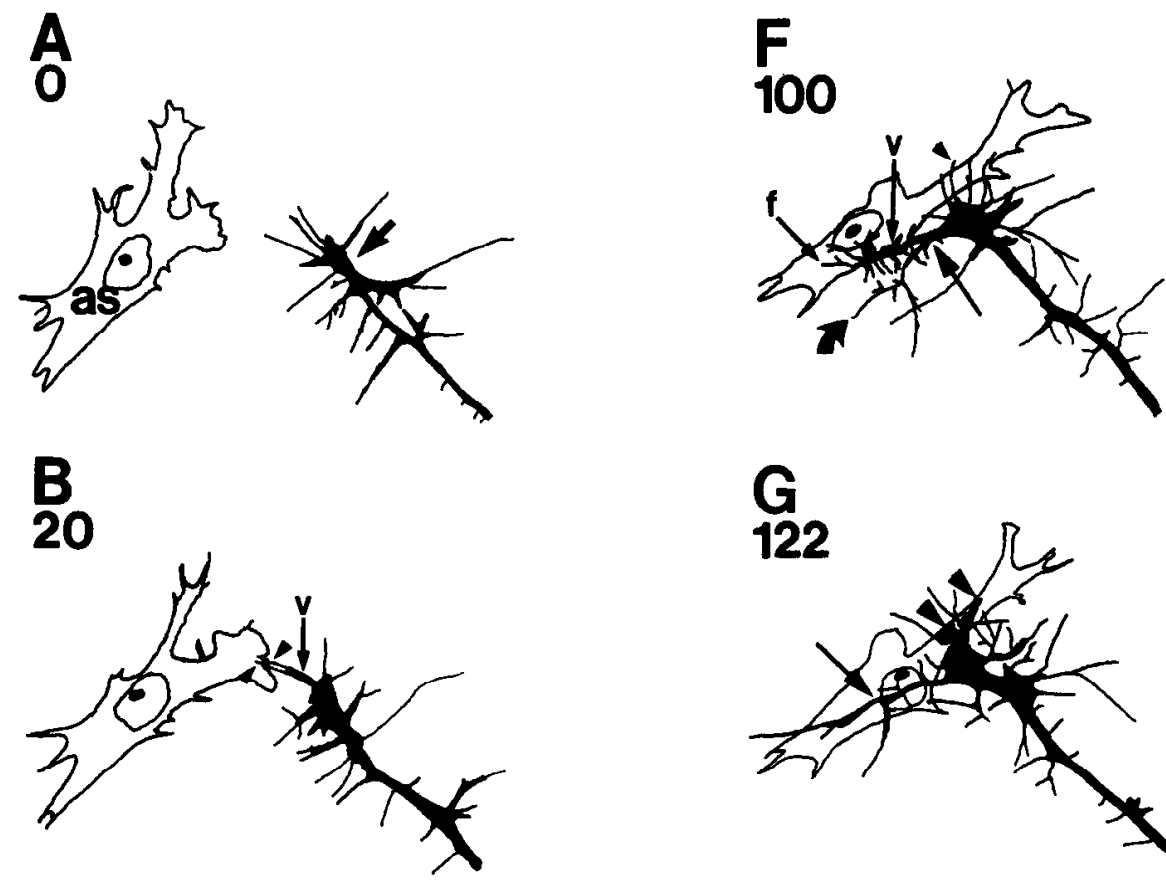

$\mathbf{G}$
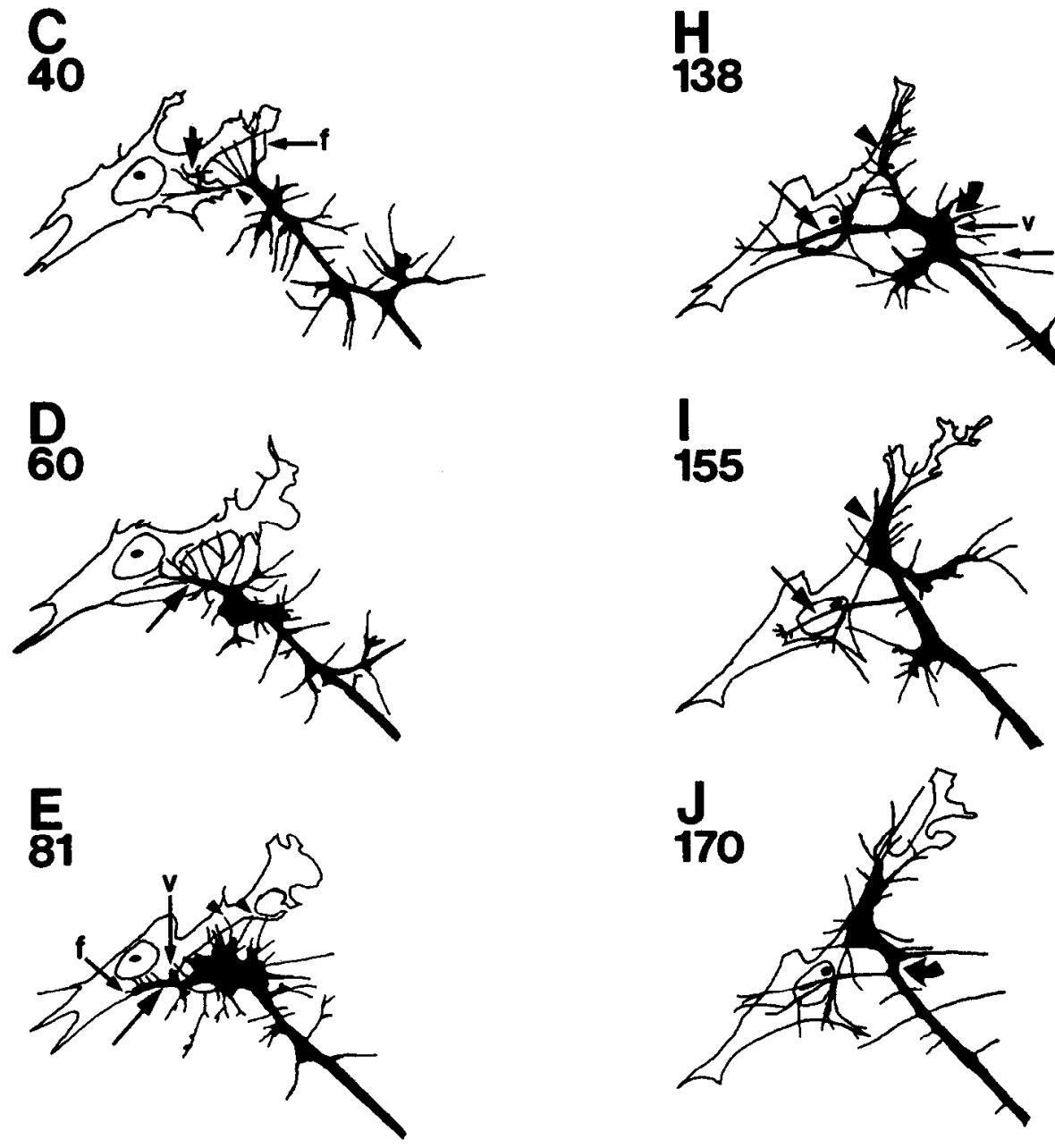
both behaviors are mediated by the activation of specific growth cone receptors by ligands associated with the membranes of the cell types avoided.

These mechanistic similarities may reconcile our results with those of Davis et al. (1990), who have demonstrated a growth cone-collapsing activity in somite extracts. The experiments of Davies and colleagues differ from ours in both the cell type used and the assay employed: sensory growth cones were exposed to liposomes containing proteins from somite extracts. Although the lack of growth cone collapse in our study could be due to the difference in cell type, the difference in the assay employed may well be key. In the collapse assay, receptors along the entire surface of the growth cone are exposed to the active agents, which could exaggerate a response that is normally local (see also Davies and Cook, 1991). The differences between these two studies emphasize the necessity of using multiple assays to appreciate fully the mechanisms of axon guidance (Tosney, 1992).

Perhaps the most interesting aspect of inhibition by posterior cells is the selective and local nature of the inhibition. The inhibition appears to affect veil protrusion alone and is limited to sites of contact. Since changes in intracellular calcium can affect motility and can be highly localized, intracellular calcium levels may be relevant. Local asymmetries in calcium fluxes have recently been documented as growth cones turn in response to electrical fields (Bedlack et al., 1992; Davenport and Kater, 1992). However, since changes in calcium influx are known to affect the protrusion of both veils (Goldberg, 1988) and filopodia (Rehder and Kater, 1992), additional regulatory events would have to be posited to account for the selective influence on veil protrusion. Regardless of the intracellular mediator involved, our results predict that one-sided contact with posterior cells should generate an asymmetry in a mediator that specifically limits veil protrusion.

The selective affinity of motor growth cones for anterior cells results from dramatic changes in motility that do not appear to be related solely to adhesive mechanisms. Adhesion-tension models of guidance suggest that growth cone turning depends on an asymmetry in the adhesive environment. Filopodia are thought to detect such differences by forming adhesive contacts that generate tension. This model predicts that turning would be due to a local asymmetry in filopodial contacts, which may result in an asymmetry in protrusive activity (Letourneau, 1975, 1983; Bray, 1987). In contrast, local contact with anterior cells resulted in a widespread increase in protrusive activity that was neither asymmetric nor limited to the site of contact. Moreover, the selective affinity for anterior cells was not correlated with either an asymmetry in filopodial contacts or the duration of those contacts. Although we cannot rule out the possibility that contacts with anterior cells generate more tension than contacts with laminin, these findings are inconsistent with a simple mechanism based solely on differential adhesion to anterior cells. We suggest that the selective affinity of motor growth cones for anterior cells is mediated by the activation of specific receptors by cell surface molecules on anterior sclerotome cells.

Although we don't know the identity of the cell surface molecules responsible for the response to anterior cells, the widespread net increase in protrusive activity we observed suggests a transduction event that globally amplifies signals generated at the site of contact. The intracellular mediators of such signals would likely act by influencing actin dynamics since actin polymerization and stability are necessary for protrusive activity

\section{A. Surface area of growth cone}

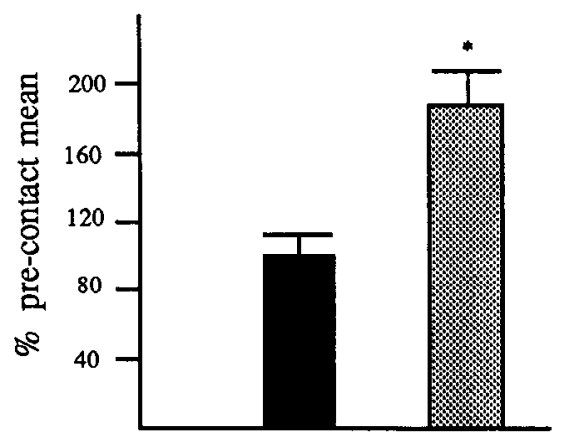

\section{B. Rate of veil protrusion}

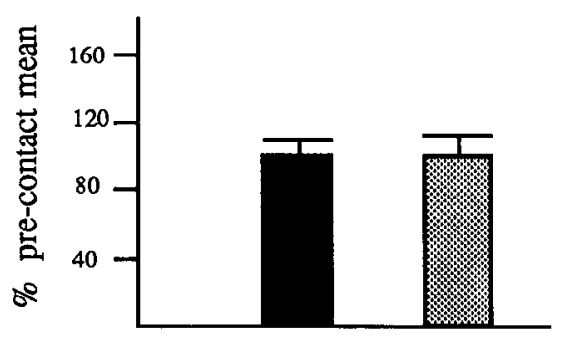

\section{Number of filopodia}

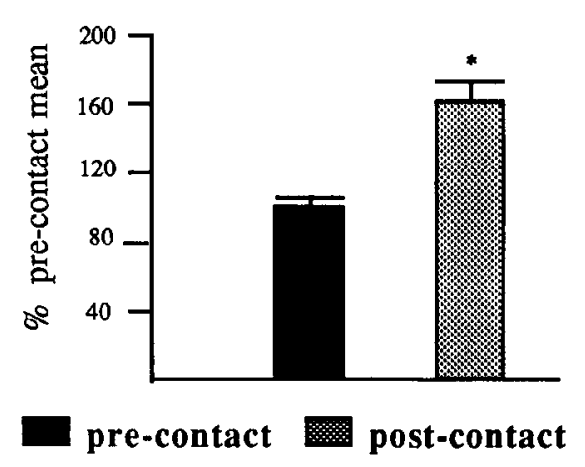

Figure 11. Contact-dependent changes in growth cone motility during perpendicular interactions with anterior sclerotome. $A$, Mean relative growth cone surface area before (solid bar) and after (shaded bar) the establishment of stable filopodial contact. In all five cases tested, the mean growth cone surface area increased significantly during the $10 \mathrm{~min}$ postcontact measurement period when compared to the precontact mean. $B$, Mean relative rates of veil protrusion before (solid bar) and after (shaded bar) the establishment of stable filopodial contact. The mean rate of veil protrusion during the postcontact period was not significantly different from the precontact mean in any of the five cases analyzed. $C$, Mean relative number of filopodia before (solid bar) and after (shaded bar) the establishment of stable filopodial contact. In all five cases tested, the mean number of filopodia increased significantly during the $10 \mathrm{~min}$ postcontact period when compared to the precontact mean. Asterisks indicate significant differences $(p<0.001)$ from precontact means; all statistical comparisons were made on individual growth cones using the paired Student's $t$ test. Error bars indicate SEM. 

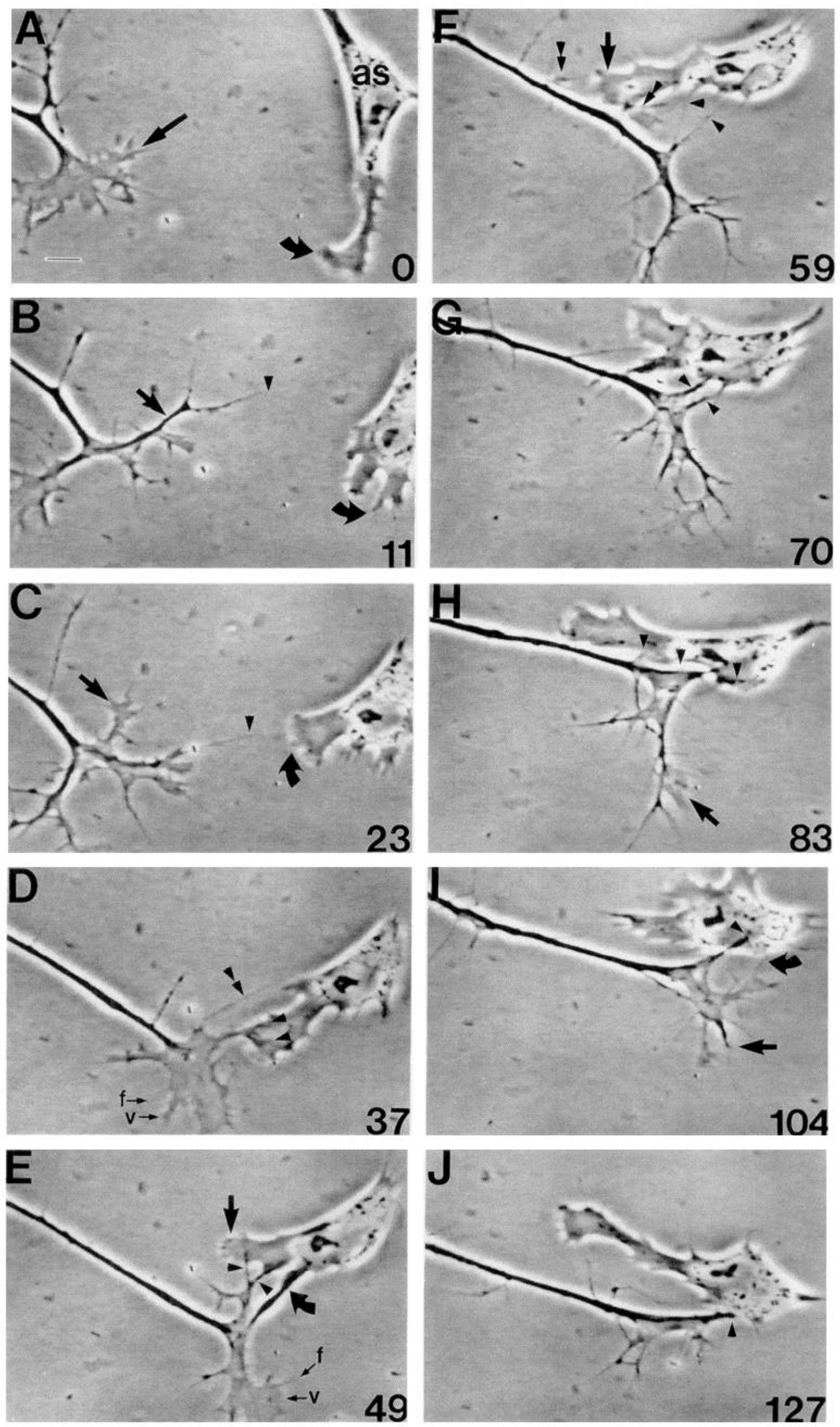

Figure 12. Video sequence of an oblique interaction with an anterior sclerotome cell. Approximate elapsed time (in minutes) is indicated at the lower right of each frame. A, A motor growth cone (straight arrow) approaches an anterior sclerotome cell (as). Note that the flattened portion of the growth cone is largely symmetrical and that the cell has an elongated lower process (curved arrow). $B$, In the interim between frames $A$ and $B$, the right side of the growth cone contacted the cell with many fine filopodial processes (e.g., arrowhead), which resulted in the consolidation (straight arrow) evident on the contacting side and the formation of a branched growth cone. The cell has changed shape in response to contact, withdrawing 
(Letourneau, 1987; Bray and White, 1988; Forscher and Smith, 1988; Mitchison and Kirshner, 1988; Burmeister et al., 1991).

Similarly, laminin elicits changes in the behavior in sympathetic growth cones that are more likely related to receptor activation than to adhesive properties. Acute addition of laminin to cultures grown on polylysine has dramatic cffccts on growth cone motility and neurite consolidation that are similar to those reported here. I aminin increases the stability of veils and filopodia and also enhances the engorgement of veils with microtubules and membranous vesicles (Rivas et al., 1992). It is unlikely that the effects of laminin are due strictly to its adhesive properties since laminin has been shown to be less adhesive than polylysine (Gundersen, 1987; Lemmon et al., 1992). These effects of laminin on growth cone motility are likely due to intracellular signals generated by the binding of integrin receptors. These signals may be amplified by the activation of protein kinase $\mathrm{C}$ (Bixby, 1989). The net increase in growth cone surface area that we detected in response to anterior cells could be due either to an increase in the number and size of veils protruded or to an increase in veil stability. Moreover, the enhancement of neurite consolidation we observed may well have been due to accelerated engorgement, since we cannot resolve these two steps using phase-contrast optics.

The response of motor growth cones to anterior cells also shares important features with the response of grasshopper sensory pioneers to guidepost neurons. In the grasshopper limb, the Til pioneer growth cones navigate a series of well-characterized turns in response to several guidance cues. One cue is provided by differentiating neurons, the guidepost cells. Single filopodial contacts can reorient the Til growth cone toward a guidepost cell (Caudy and Bentley, 1986; O'Connor et al., 1990). In this system, the contacting filopodium is selectively invaded by microtubules after it dilates and forms a new segment of the nascent axon (O'Connor et al., 1990; Sabry et al., 1991). Thus, as a result of only limited contact and despite extensive protrusions in other directions, the Til growth cone reorients toward the guidepost cell. Motor growth cone behavior resembles that of Til growth cones in two ways. First, we observed similar reorientations toward anterior sclerotome cells following only limited contact and in spite of extensive protrusions on the laminin substrate. Both Til growth cones and motor growth cones selectively eliminated branches that did not contact the guiding cell (O'Connor et al., 1990; present results). Second, motor growth cone processes that contacted anterior cells often thickened, taking on the appearance of a consolidated neurite. This enhanced consolidation resembles the contact-dependent dilation of Ti1 filopodia. It will be important to determine if processes that contact anterior cells are also selectively invaded by microtubules.

\section{Growth cone motility and axon guidance}

Our obscrvations raisc questions as to the role of filopodia in axon guidance. Models of axon guidance based on differential adhesion suggest that filopodia act to pull the growth cone forward: steering results from a bias in this pulling toward the side of the growth cone that produces more tension via more adhesive contacts (Letourneau, 1983; Gundersen and Park, 1984; Bray, 1987). A prediction of this model is that growth cone steering would be biased toward more persistent filopodial contacts on one side. However, our results show that motor growth cones turned away from posterior cells in spite of more persistent filopodial contacts with these cells. Moreover, motor growth cones turned toward anterior cells in the absence of any asymmetry in filopodial distribution or persistence and in spite of extensive substrate contacts. Our results are therefore inconsistent with a simple adhesion-based model of guidance. Recent culture studies of axon outgrowth on purified adhesion molecules also support the conclusion that the direction of outgrowth is not exclusively determined by differential adhesion (Gundersen, 1987; Calof and Lander, 1991; Lemmon et al., 1992). Furthermore, since we did observe dramatic changes in growth cone motility after only limited filopodial contact, our results support the idea that filopodia serve as long-distance sensors of environmental cues that guide axons by influencing growth cone motility and neurite maturation. This conclusion is also supported by the findings of Bentley and colleagues (Caudy and Bentley, 1986; O'Connor et al., 1990) and is consistent with the localization of specific receptors at the tips of filopodia (Letourneau and Shattuck, 1989).

Interactions with posterior sclerotome cells further suggest an important role for veil extension in growth cone guidance. In oblique interactions, we found that asymmetries in veil distribution generated by local inhibition of protrusion predicted the subsequent direction of growth: the growth cone proceeded in the direction of continued veil protrusion. These findings support the idea that the veil represents the nascent axon (Goldberg and Burmeister, 1986). Thus, some guidance cues act by producing asymmetries in veil extension.

\section{Mechanisms of motor axon segmentation}

Are the contact-dependent changes in growth cone motility that we have documented responsible for motor axon segmentation

\footnotetext{
the elongated lower process (curved arrow) and extending others. $C$, The consolidation on the right side is transient (compare $B$ ) and further filopodial contact (e.g., arrowhead) with the cell stimulates a profusion of activity, even in regions removed from the sites of contact (straight arrow). The cell has extended toward the growth cone (curved arrow; compare $B$ ) in response to contact. $D$, The growth cone extends veils (single arrowheads) onto the cell, which continues to extend slowly toward the growth cone. The growth cone continues to extend veils (v) and filopodia $(f)$ onto the substrate as well as filopodia (e.g., double arrowhead) that contact the cell. Also note that the entire left branch of the growth cone has been resorbed (compare $C$ ). E. Filopodia that establish stable contact with the cell thicken (arrowheads; compare $D$ ) as if to consolidate a new neurite. The cell responds to sustained contact with the veils by condensing and resorbing the lower process (curved arrow) while extending another, upper process (straight arrow) in response to new filopodial contact. The growth cone continues to grow on the substrate extending broad veils ( $v$ ) between filopodia $(f), F$, Protrusive activity (double arrowheads) is stimulated in the consolidated portion of the neurite as the upper process (arrow) of the cell contacts it. The lower process of the cell has completely withdrawn but the growth cone remains tethered to the cell by fine filopodia (single arrowheads). $G$, A burst of protrusive activity on the contacting side of the growth cone has drawn the growth cone toward the cell in the interim between $F$ and $G$. Note the thickening of processes (arrowheads) contacting the cell (compare $F$ ). $H$, Protrusive activity of both the growth cone and the cell result in broad contact between the two (arrowheads) while the distal part of the growth cone (arrow) remains active on the substrate. $I$, The growth cone extends a very simple consolidated process (arrowhead) onto the cell as the cell retracts from the proximal neurite. Much of the distal part of the growth cone has been resorbed (straight arrow) as other distal processes (curved arrow) begin to make contact with the cell. $J$, The highly consolidated growth cone (arrowhead) remains in contact with the cell as most other processes are resorbed. Scale bar, $10 \mu \mathrm{m}$.
} 


\section{A. Surface area of growth cone}

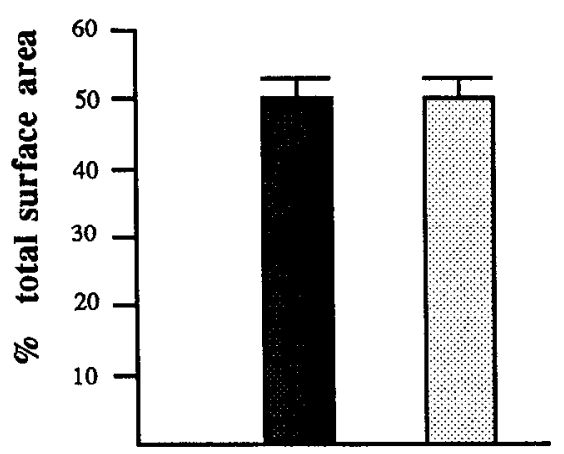

\section{B. Number of filopodia}

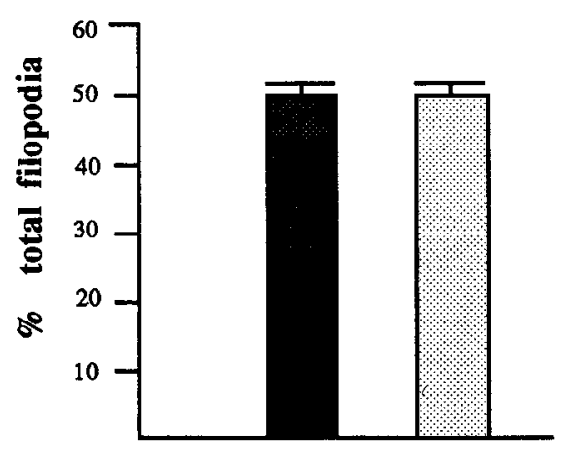

\section{Retention of filopodia}

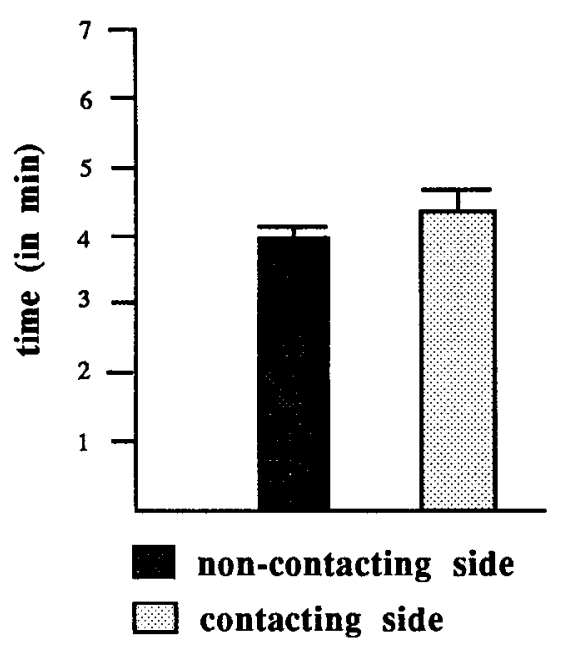

Figure 13. Contact-dependent changes in growth cone motility during oblique interactions with anterior sclerotome. This figure illustrates a side-to-side comparison of interactions in which only one side of the growth cone contacts the anterior cell. In all graphs, the cell-contacting side (light bar) is compared to the noncontacting side (dark bar) during a 20-30 min measurement period after the establishment of stable filopodial contact. $A$, The comparison of mean growth cone surface area shows no significant asymmetry in growth cone surface area. $B$, Comparison of the mean number of filopodia protruded on either side of the growth cone shows no significant asymmetry in the distribution of filopodia. $C$, Comparison of the mean retention time of cell contacting filopodia and noncontacting filopodia shows that filopodia that contact anterior cells are not retained significantly longer than those that contact in vivo? A role for contact-dependent mechanisms is supported by the pattern of early motor outgrowth as revealed in fixed embryos. Motor growth cones exit the neural tube opposite both the anterior and posterior sclerotome (Dehnbostel and Tosney, 1990; Lim et al., 1991). Those that exit opposite posterior cells turn sharply only after contacting posterior cells (Dehnbostel and Tosney, 1990). This pattern of outgrowth is consistent with the contact-mediated avoidance behavior documented herein.

Is motor axon segmentation mediated exclusively by contactdependent mechanisms? Our results do not preclude the possibility that chemotactic or chemotrophic mechanisms may act in concert with contact-mediated mechanisms. In preliminary studies, we have found that motor outgrowth on explanted somites is often biased toward the nearest anterior sclerotome (Oakley and Tosney, 1989; also see Tosney, 1991). Since motor neurites orient toward the nearest anterior sclerotome in the apparent absence of contact, an additional, contact-independent cue may be important. A chemotactic mechanism has also been suggested to explain the trajectory of motor axons that exit the neural tube opposite posterior sclerotome: these axons turn toward the nearest anterior sclerotome (Keynes et al., 1991; Lim ct al., 1991). Since the anterior cells may be well beyond filopodial reach, the direction of turning is suggestive of a chemotactic mechanism. However, our results predict that a similar growth pattern could result from contact-dependent mechanisms. For example, contact with posterior cells may lead to orthogonal branching and the generation of two growth cones. If so, then the growth cone directed toward the nearest anterior sclerotome would be more likely to advance since filopodial contact with anterior cells would eventually stimulate both protrusive activity and the subsequent consolidation of the motor axon.

Motor axon segmentation is likely due to the combined influence of both positive and negative guidance cues. Our results suggest that the anterior sclerotome stimulates protrusive activity and enhances axon consolidation whereas the posterior sclerotome locally inhibits veil extension. We suggest that patterned outgrowth thus results from the juxtaposition of two contrasting environments that differentially influence growth cone motility.

\section{Mechanisms of guidance by general cues}

Similar sets of contrasting environments may provide general guidance cues in other regions of the embryo. For example, growth cones turn at the base of the limb when confronted with a choice between the girdle mesenchyme and the adjacent plexus mesenchyme (Tosney and Landmesser, 1984). Similarly, growth cones extend within the dorsal anterior sclerotome but avoid the perinotochordal mesenchyme (Tosney and Landmesser, 1985a). Since surgical experiments have shown the girdle mesenchyme (Tosney and Landmesser, 1984) and the perinotochordal mesenchyme (Tosney and Oakley, 1990) to be inhibitory environments, these tissues share functional characteristics with the posterior sclerotome. Moreover, all three of these inhibitory tissues share a similar molecular profile: they all express PNA binding and chondroitin-6-sulfate epitopes. These markers are not expressed in adjacent axon pathways (Oakley and Tos-

$$
\longleftarrow
$$

the substrate $(N=44)$. All statistical comparisons were made using the Student's $t$ test. Error bars indicate SEM. 
ney, 1991). Based on these functional and molecular similarities, we have suggested that axon guidance at these sites is due to a common set of cellular interactions (Tosney and Oakley, 1990). This hypothesis predicts that contact with girdle mesenchyme or perinotochordal cells should locally inhibit veil formation as we have shown here for posterior sclerotome cells. Conversely, contact with plexus mesenchyme should stimulate protrusive activity and enhance neurite consolidation. It will be important to test this hypothesis to determine if guidance is due to the same mechanisms in all cases. Once the mechanisms of guidance are defined, the problem of identifying the molecules that elicit these changes in growth cone motility will be simplified.

\section{References}

Ball EE, Ho RK, Goodman CS (1985) Development of neuromuscular specificity in the grasshopper embryo: guidance of motoneuron growth cones by muscle pioneers. J Neurosci 5:1808-1819.

Bandtlow C, Zachleder T, Schwab ME (1990) Oligodendrocytes arrest neurite outgrowth by contact inhibition. J Neurosci 10:3837-3848.

Bedlack RS, Wei MD, Loew LM (1992) Localized membrane depolarizations and localized calcium influx during electric field-guided neurite growth. Neuron 9:393-403.

Bixby JL (1989) Protein kinase $C$ is involved in laminin stimulation of neurite outgrowth. Neuron 3:287-297.

Bottenstein JE, Skaper SD, Varon SS, Sato GH (1980) Selective survival of neurons from chick embryo sensory ganglionic dissociates utilizing serum-free supplemented medium. Exp Cell Res 125:183190.

Bray D (1987) Growth cones: do they pull or are they pushed? Trends Neurosci 10:431-434.

Bray D, White JG (1988) Cortical flow in animal cells. Science 239: 883-888.

Burmeister DW, Rivas RJ, Goldberg DJ (1991) Substrate-bound factors stimulate engorgement of growth cone lamellipodia during neurite elongation. Cell Motil Cytoskel 19:255-268.

Calof AL, Lander AD (1991) Relationship between neuronal migration and cell-substratum adhesion: laminin and merosin promote olfactory neuronal migration but are anti-adhesive. J Cell Biol 115: 779-794.

Caudy M, Bently D (1986) Pioneer growth cone steering along a series of neuronal and non-neuronal cues of different affinities. J Neurosci 6:1781-1795.

Cohan CS, Connor JA, Kater SB (1987) Electrically and chemically mediated increases in intracellular calcium in neuronal growth cones. J Neurosci 7:3588-3599.

Cox EC, Muller B, Bonhoeffer F (1990) Axonal guidance in the chick visual system: posterior tectal membranes induce collapse of growth cones from the temporal retina. Neuron 2:31-37.

Davenport RW, Kater SB (1992) Local increases in intracellular calcium elicit local filopodial responses in Helisoma neuronal growth cones. Neuron 9:405-416.

Davies JA, Cook GMW (1991) Growth cone inhibition-an important mechanism in development? Bioessays 13:11-15.

Davies JA, Cook GMW, Stern CD, Keynes RJ (1990) Isolation from chick somites of a glycoprotein fraction causes collapse of dorsal root ganglion growth cones. Neuron 4:11-20.

Dehnbostel D, Tosney KW (1990) Initial motor axon outgrowth. Soc Neurosci Abstr 16:1006.

Detwiler SR (1934) An experimental study of spinal nerve segmentation in Ambystoma with reference to the plurisegmental contribution to the brachial plexus. J Exp Zool 67:395-441.

Eisen JS, Myers PZ, Westerfield M (1986) Pathway selection by growth cones of identifiied motoneurons in live zebrafish embryos. Nature 320:269-271.

Forscher P, Smith SJ (1988) Actions of cytochalasins on the organization of actin filaments and microtubules in the neuronal growth cone. J Cell Biol 107:1505-1516.

Goldberg DJ (1988) Local role of $\mathrm{Ca}^{2+}$ in formation of veils in growth cones. J Neurosci 8:2596-2605.

Goldberg DJ, Burmeister DW (1986) Stages in axon formation: observations of growth of Aplysia axons in culture using video-enhanced contrast-differential interference contrast microscopy. J Cell Biol 103: 1921-1931.

Goldberg DJ, Burmeister DW (1989) Looking into growth cones. Trends Neurosci 12:503-506.

Gundersen RW (1987) Response of sensory growth cones to patterned substrata of laminin and fibronectin in vitro. Dev Biol 121:423-431.

Gundersen RW, Barrett JN (1980) Characterization of the turning response of dorsal root neurites toward nerve growth factor. J Cell Biol 87:546-554.

Gundersen RW, Park KHC (1984) The effects of conditioned media on spinal neurites: substrate-associated changes in neurite direction and adherence. Dev Biol 104:18-27.

Hamburger V, Hamilton HL (1951) A series of normal stages in the development of the chick embryo. J Morphol 88:49-92.

Harrison RG (1910) The outgrowth of the nerve fiber as a mode of protoplasmic movement. J Exp Zool 9:787-846.

Haydon PG, McCobb DP, Kater SB (1984) Serotonin selectively inhibits growth cone motility and synaptogenesis of specific identified neurons. Science 226:561-564.

Hinkle L, McCaig CD, Robinson KR (1981) The direction of growth of differentiating ncurons and myoblasts from frog cmbryos in an applied electrical field. J Physiol (Lond) 314:121-135.

Honig MG, Hume RI (1986) Fluorescent carbocyanine dyes allow living neurons of identified origin to be studied in long term cultures. J Cell Biol 103:171-187.

Johansen J, Halpern ME, Keshishian H (1989) Axonal guidance and the development of muscle fiber-specific innervation in Drosophila embryos. J Neurosci 9:4318-4332.

Johnston AR, Gooday DJ (1991) Xenopus temporal retinal neurites collapse on contact with glial cells from caudal tectum in vitro. Development 113:409-417.

Kapfhammer JP, Raper JA (1987a) Collapse of growth cone structure on contact with specific neurites in culture. J Neurosci 7:201-212.

Kapfhammer JP, Raper JA (1987b) Interactions between growth cones and ncuritcs growing from different ncural tissues in culture. J Neurosci 7:1595-1600.

Kater SB, Mills LR (1991) Regulation of growth cone behavior by calcium. J Neurosci 11:891-899.

Keynes RJ, Stern CD (1984) Segmentation in the vertebrate nervous system. Nature 310:786-789.

Keynes RJ, Jaques KF, Cook GMW (1991) Axon repulsion during peripheral nerve segmentation. Development [Suppl] 2:131-139.

Lance-Jones C, Landmesser LT (1981a) Pathway selection by lumbosacral motoneurons during normal development. Proc R Soc Lond [Biol] 214:1-18.

Lance-Jones C, Landmesser LT (1981b) Pathway selection by embryonic chick motoneurons in an experimentally altered environment. Proc R Soc Lond [Biol] 214:19-52.

Landmesser LT (1988) Peripheral guidance cues and the formation of specific motor projections in the chick. In: From message to mind (Easter SS, Barald KF, Carlson BM, eds), pp 121-133. Sunderland, MA: Sinauer.

Lemmon V, Burden SM, Payne HR, Elmslie GW, Hlavin ML (1992) Neurite growth on different substrates: permissive versus instructive influences and the role of adhesive strength. J Neurosci 12:818-826.

Letourneau PC (1975) Cell-to-substratum adhesion and guidance of axonal elongation. Dev Biol 44:92-101.

Letourneau PC (1978) Chemotactic response of nerve fiber elongation to nerve growth factor. Dev Biol 66:183-196.

Letourneau PC (1983) Axonal growth and guidance. Trends Neurosci 6:451-455.

Letourneau PC (1987) Pull and push in neurite elongation: observations on the effects of cytochalasin B and taxol. Cell Motil Cytoskel 8:193-209.

Letourneau PC, Shattuck TA (1989) Distribution and possible interactions of actin associated proteins and cell adhesion molecules of nerve growth cones. Development 105:505-519.

Letourneau PC, Shattuck TA, Roche FK, Takeichi M, Lemmon V (1990) Nerve growth cone migration onto Schwann cells involves the calcium-dependent adhesion molecule, $N$-cadherin. Dev Biol 138: 430-442.

Letourneau PC, Roche FK, Shattuck TA, Lemmon V, Takeichi M (1991) Interactions of Schwann cells with neurites and with other Schwann cells involve the calcium-dependent adhesion molecule, $\mathrm{N}$-cadherin. J Neurobiol 22:707-721. 
Lim T, Jaques KF, Stern CD, Keynes RJ (1991) An evaluation of myelomeres and segmentation of the chick embryo spinal cord. Development 113:227-238.

Loring JF, Erickson CA (1987) Neural crest cell migratory pathways in the chick embryo. Dev Biol 121:230-236.

Meiri KF, Burdick D (1991) Nerve growth factor stimulation of GAP43 phosphorylation in intact isolated growth cones. J Neurosci 11: 3155-3164.

Mitchison T, Kirshner M (1988) Cytoskeletal dynamics and nerve growth. Neuron 1:761-772.

Moorman SJ, Hume RI (1990) Growth cones of chick sympathetic preganglionic neurons in vitro interact with other neurons in a cellspecific manner. J Neurosci 10:3158-3163.

Oakley RA, Tosney KW (1989) Analysis of the cellular interactions that mediate the development of motor axon segmentation. Soc Neurosci Abstr 15:875.

Oakley RA, Tosney KW (1991) Peanut agglutinin and chondroitin6-sulfate are molecular markers for tissues that act as barriers to axon advance in the avian embryo. Dev Biol 147:187-206.

O'Conner TP, Duerr JS, Bently D (1990) Pioneer growth cone steering decisions mediated by single filopodial contacts in situ. J Neurosci 10:3935-3946.

Patel NB, Poo MM (1982) Orientation of neurite growth by extracellular electric fields. J Neurosci 2:483-496.

Ramon y Cajal S (1890) A quelle epoque apparaissent les expansions des cellules nerveuses de la moelle epiniere du poulet. Anat Anz 5:609-613.

Rehder V, Kater SB (1992) Regulation of neuronal growth cone filopodia by intracellular calcium. J Neurosci 12:3175-3186.

Rickmann M, Faucet JW, Keynes RJ (1985) The migration of neural crest cells and the growth of motor axons through the rostral half of the chick somite. J Fmbryol Exp Morphol 90:437-455.

Rivas RJ, Burmeister DW, Goldberg DJ (1992) Rapid effects of laminin on the growth cone. Neuron 8:107-115.
Sabry JH, O'Conner TP, Evans L, Toroian-Raymond A, Kirshner M, Bentley D (1991) Microtubule behavior during guidance of pioneer neuron growth cones in situ. J Cell Biol 115:381-395.

Stern CD, Keynes RJ (1987) Interactions between somite cells: the formation and maintenance of segment boundaries in the chick embryo. Development 99:261-272.

Stern CD, Sisodiya SM, Keynes RJ (1986) Interactions between neurites and somite cells: inhibition and stimulation of nerve growth in the chick embryo. J Embryol Exp Morphol 91:209-226.

Tosney KW (1987) Proximal tissues and patterned neurite outgrowth at the lumbosacral level of the chick embryo: deletion of the dermamyotome. Dev Biol 122:540-588.

Tosney KW (1988) Proximal tissues and patterned neurite outgrowth at the lumbosacral level of the chick embryo: partial and complete deletion of the somite. Dev Biol 127:266-286.

Tosney KW (1991) Cells and cell-interactions that guide motor axons in the developing chick embryo. Bioessays 13:1-7.

Tosney KW (1992) Growth cone navigation in the proximal environment of the chick embryo. In: The nerve growth cone (Letourneau PC, Kater SB, Macagno ER, eds), pp 231-236. New York: Raven.

Tosney KW, Landmesser LT (1984) Pattern and specificity of axonal outgrowth following varying degrees of chick limb bud ablation. J Neurosci 4:2518-2527.

Tosney KW, Landmesser LT (1985a) Development of the major pathways for neurite outgrowth in the chick hindlimb. Dev Biol 109:193214.

Tosney KW, Landmesser LT (1985b) Specificity of motoneuron growth cone outgrowth in the chick hindlimb. J Neuroci 5:2336-2344.

Tosney KW, Landmesser LT (1985c) Growth cone morphology and trajectory during outgrowth into the chick limb. J Neurosci 5:23452358.

Tosney KW, Oakley RA (1990) The perinotochordal mesenchyme acts as a barrier to axon advance in the chick embryo: implications for a general mechanism of axon guidance. Exp Neurol 109:75-89. 